\title{
A New Approach for Allocating a New Party's Budget during an Election Campaign
}

Irit Talmor ${ }^{12}$ and Osnat Akirav ${ }^{3}$

Received: 12 November 2020 | Accepted: 29 June 2021 | Published: 8 July 2021

\begin{abstract}
During pre-election campaigns, parties make great efforts to persuade constituents to vote for them. Usually, new parties have smaller budgets and fewer resources than veteran parties. Generally, the more heterogeneous the party's electorate, the more critical the issue of resource allocation. This paper presents a method for new parties to efficiently allocate campaign advertising resources and maximise voters. The model developed uses the Pareto principle and multi-criteria approach, integrating the party's confidential data together with official open-to-all data. We implemented the model on a specific new party during the intensive political period before the April 2019 elections in Israel, finding that the model produced clear and unbiased results, and this made it effective and user-friendly for strategy teams and campaign managers.
\end{abstract}

Keywords: election campaign; Multi-Criteria Decision Making; in-depth surveys; voting patterns; Pareto approach

\section{Introduction}

The pre-elections political campaign of a new party can be compared to the marketing campaign for a new commercial product (Lilien et al., 1992; O'Cass, 1996; Henneberg, 2008). In both campaigns, huge efforts are made to persuade voters (consumers) to choose the new party (product) over better-known ones (Gordon et al., 2012). However, there are some important differences between these campaigns. The first involves the degree of freedom available. Private companies are free to decide when to launch their commercial campaign and when to end it, whereas political parties must conduct their campaigns during a time frame that is dictated by law. Another important difference is related to the timing of the marketing campaign; unlike standard marketing campaigns, the election campaign of a new party is conducted simultaneously with those of all other parties.

1 Irit Talmor is a senior lecturer and head of the Logistics Department at Sir Harry Solomon School of Management. She may be contacted at irit.tlmr@gmail.com.

2 Corresponding Author

3 Osnat Akirav is a professor at and the head of the Department of Political Science at Western Galilee College. She may be contacted at osnatak@bezeqint.net 
In this article, we present an approach for supporting a new party's strategic decisions in budget allocation. Our approach is novel in two regards. First, it utilises a multi-criteria decision making (MCDM) methodology and various techniques to weight criteria in the context of political campaigns. Second, our model is tested using a combination of a party's confidential dataset and information from public databases. The advantages of our model are its transparency and simplicity, which make it a useful tool for campaign managers and party leaders. As a case study, we implemented the model during the April 2019 election in Israel.

\section{Voting behaviour}

The theoretical literature on voting behaviour has shown that a rational voter may sometimes decide to vote for a candidate or party that is not his or her first preference (e.g., Cox \& Shugart, 1996; Farquharson, 1969; Felsenthal \& Brichta, 1985). Such voters are traditionally called "strategic voters", in contrast to voters who always vote for their first preference regardless of how others are likely to vote. Farquharson (1969) was the first to propose a model attempting to trace the calculations of strategic voters. His successors examined strategic voting by focusing on entry barriers in multi-member districts (Cox \& Shugart, 1996). They showed that voters desert both weak parties and parties that seemed guaranteed to win because they are concerned about wasting their votes.

One must distinguish between the allocation of resources before elections and the allocation of resources afterwards. The former is aimed at persuading voters to change their preferences, while the latter seeks to retain current voters and increase their numbers (Lazarus \& Reiley, 2010; Levitt et al., 1997; Squire, 1995). For example, studies found that constituents increase their support for incumbents when more resources are allocated to their district. To gain this support, incumbents must continuously convince constituents that expenditures in their district are a direct result of the actions of the party or the incumbents.

Studies have discussed this issue extensively, mainly in electoral systems such as the "winner takes all" approach used in the United States. Researchers have also investigated this issue from the point of view of voters, assuming that individual voting preferences are affected by the exposure achieved by candidates and the tone of the coverage (Bartels, 1988; Cohen et al., 2004; Gordon et al., 2012; Shachar, 2009).

\section{Campaign finance and management}

Although large and veteran parties face many challenges (Poguntke et al., 2016), they still have advantages over new parties. A large, veteran party has a steady core of loyal voters who always vote for it, can present proof of tangible results to actual and potential constituents, and has a steady federal budget to support its activities. None of these advantages exists for smaller or newer parties. Smaller and newer parties must overcome additional obstacles, such as making themselves known to voters, attracting their attention, and exciting voters in a way that will draw their support. Overcoming these obstacles is very ambitious, but essential for new parties to gain parliamentary seats. 
Given these factors, new parties' advertising during their campaign should be as precise and targeted as possible. Achieving this precision is not a simple task, given the abundance of advertising alternatives and their various target audiences.

These are very ambitious goals. To achieve them, the campaign must be very convincing. It must appeal to voters' logic, and to a certain extent their feelings. Given new parties' limited resources, the importance of a campaign focused on voters among whom these goals can be achieved cannot be overemphasised. The model presented in this paper offers a way to translate a theoretical cost-benefit analysis into a practical roadmap for a new political party by prioritising clusters of potential voters using characteristics identified from in-depth interviews.

Obviously, a portion of any campaign's budget should be devoted to data collection. In-depth interviews are useful for achieving this goal. This popular type of qualitative research can collect detailed questionnaires and data from focus groups. Empirical data analysis can then provide the basis for planning the best possible campaign. Ideally, interviews should indicate the party's strengths and weaknesses; help planners understand which issues and ideas the party should emphasise, play down or change; and identify the characteristics of potential voters. Such insights are valuable for all parties, but they are indispensable for smaller, newer parties that lack a voting history and practical experience (on one hand) and must surmount significant budgetary limitations (on the other). Previous studies in political marketing used a combination of in-depth interviews and historical data regarding parties' vote share and census statistics (to monitor the demographic structure of a constituency) to develop a planning model for political marketing (Baines et al., 2002; Shea, 1996). Yet, the issue of allocating campaign resources is rarely investigated in the academic literature. Snyder (1989) analyses the case of two parties' competition for legislative seats across districts, when the goal of each party is to maximize the expected number of seats or when the goal is to maximize the probability of winning a majority of the seats.

While a new party's decision to launch a campaign may resemble efforts to market a new product, there are some important differences. First is the degree of freedom available. Private corporations are free to decide when to launch their commercial campaign and when to end it, whereas political parties must conduct their political campaigns during a set time frame that is dictated by external circumstances and considerations. Moreover, early elections often occur in Israel, creating a great deal of uncertainty and difficulties in campaign organisations, particularly for new parties. Another important difference is related to the timing of the marketing campaign. Unlike standard marketing campaigns, new parties' election campaigns are conducted simultaneously with those of their competitors. Furthermore, given that voters' (customers') decision is a one-time event that cannot be changed or cancelled, at least until the next election, there is no room for mistakes.

Given these factors, the advertising utilised by a new party should be as precise and targeted as possible during the campaign. Achieving this precision is not a 
simple task, given the abundance of advertising alternatives and their various target audiences.

\section{Israel's political system}

Israel has a unicameral parliament (the Knesset) whose members are elected by a closed-list system of proportional representation, with the entire country serving as one constituency. Its political system has been described as a hybrid, combining electoral rules, a fragmented party system, and bipolar competition (Rahat \& Hazan, 2005; Shugart, 2011).

In the run-up to the elections, parties launch campaigns to persuade voters to support them. Such campaigns are very expensive. To compensate for the fact that some parties have more money than others, the state participates in the financing of campaigns by allocating "funding units" to each party. Each funding unit equals a certain amount of money set by law. The units are distributed among the parties as follows: parties that have gained enough votes to have seats in the Knesset receive a number of units equal to the number of mandates obtained; parties that have not won any seats in the Knesset, but have garnered at least $1 \%$ of the votes, receive one funding unit; and parties that have not passed the $1 \%$ threshold do not receive any funding units. ${ }^{4}$ This method rewards large, veteran parties with proven track records that can afford to run expensive campaigns. In contrast, smaller and newer parties that are not currently serving in the Knesset and/or are embarking on their first political campaign have much tighter budgetary constraints.

\footnotetext{
${ }^{4}$ https://www.idi.org.il/articles/25939
}

All of the 34 OECD countries, except Switzerland, have funding units by law. Hence, the concept that parties should have special budgets for their campaigns during the election is common and well established in democracies. However, compared to the other OECD countries, the parties in Israel receive much more money because of strong restrictions regarding donations to political parties.

The case of Israel, with its proportional representation system, was analysed by several scholars who found that neither political preference nor coalition expectations differ systematically between those who support their most preferred party and those who support other parties (Felsental \& Brichta, 1985). Three recent studies convincingly demonstrated how coalition preferences affect the voters' choices beyond party or leader preferences. Blais et al. (2006) showed that, in the 2003 Israeli elections, coalition preferences led one in ten voters to support a party other than the one they preferred most. Similarly, Abramson et al. (2006) demonstrated that, in the 2006 Israeli elections, voters acted strategically to help create the coalition they desired. Bargsted and Kedar (2009) identified the ideological dimension of strategic coalition voting more precisely. They found that leftist voters deserted the Labor Party when the party was unlikely to participate in a government coalition and instead opted for a centrist party, the "lesser of two evils".

\section{Methodology}

To determine an effective allocation for a new party's financial resources, we 
utilised a multi-criteria decision making (MCDM) approach. This approach applies a structured process to select the best alternative out of a finite set of alternatives, in accordance with a set of pre-defined criteria. Assuming that decision-makers have the ability to express their opinions on each alternative and regarding each decision criteria, the difficulty derives from the fact that the evaluation and ranking of all alternatives should be done in accordance with all criteria simultaneously.

The MCDM approach and its ranking methods have been the focus of a great deal of attention in the academic literature. Comprehensive and detailed reviews appear in Triantaphyllou (2000); Ishizaka and Nemery (2013); and Zopounidis and Doumpos (2017). This approach is widely used in real-life issues regarding such diverse subjects as economics (Doumpos \& Zopounidis, 2014; Wan et al., 2018) and engineering (Liu et al., 2019; Wan et al., 2018). However, it is rarely used in the context of elections or political campaign. A unique example of implementing MCDM to analyse the problem of selecting candidates in e-voting is found in Alguliyev et al. (2019).

The goal of our model is to determine the localities in which a new political party would be best advised to utilise its budget for maximum effect. To the best of our knowledge, the current study is the first to demonstrate the power of MCDM in the context of resource management during election campaigns. Furthermore, the simplicity and clarity of our approach allow campaign managers to easily follow its rationale and use it to make strategic decisions. In the next sections, we will describe the implementation of our approach within a specific case study, step by step.

\section{Case study}

Forty parties competed in Israel's 2019 election; 29 of them were new. One such party was "Zehut" (hereafter denoted by the letter " $Z$ "). Although "Z" was unknown at the beginning of the campaign and had few resources, its strategic team was determined to maximise the party's achievements in the election. One issue debated by the team was the allocation of funding among various advertising alternatives (i.e., digital and physical media, press, social networks, etc.). A sub-issue in this context was how to prioritise the allocation of the resources for physical media such as outdoor signage, flyers, and billboards among the different localities. The strategy team asked the author for advice regarding this issue. On this mission, the author concentrated on focusing and ranking, following a five-stage process-shown in Figure 1 and explained hereafter.

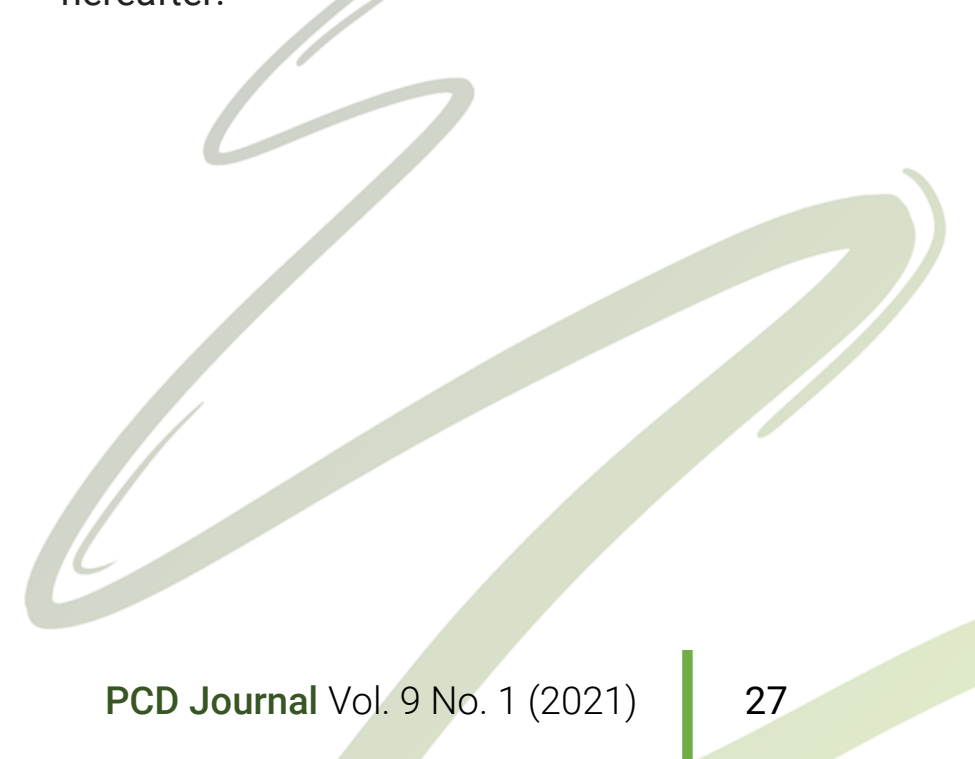


Figure 1. Analysis Process

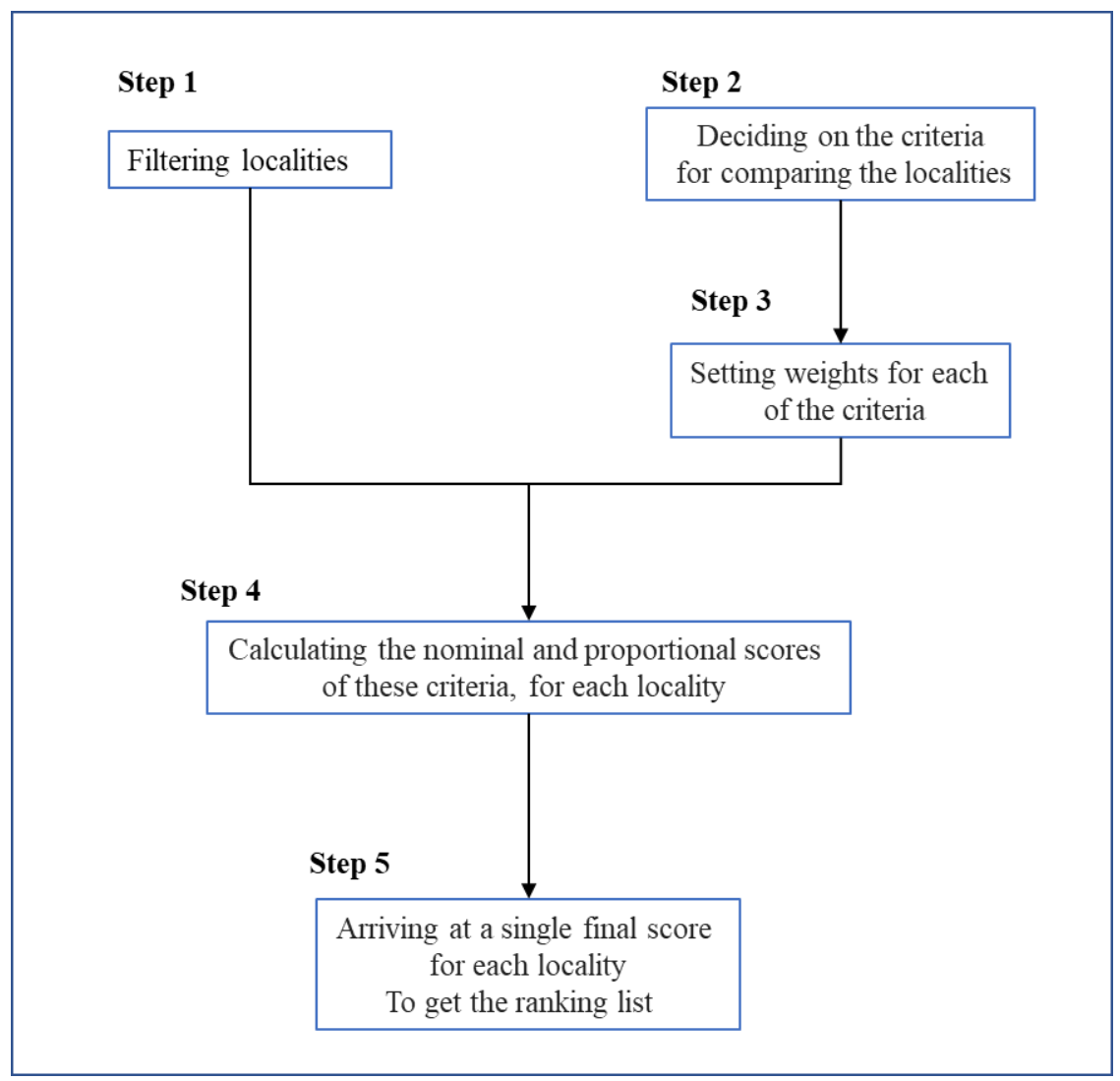

\section{Step 1: Filtering localities}

According to official data, there were 1,195 localities in Israel in 2019. Dealing with so many localities was impractical, so we conducted a preliminary, two-stage process to select the main localities on which to focus. First, we identified 145 localities whose electoral profile was homogeneous and very different from the platform of " $Z$ ", then removed them from the list. In the second stage, we applied the Pareto principle. The 1,050 remaining localities were sorted in descending order based on the number of voters, until the threshold of $80 \%$ of relevant voters was reached. At the end of this second stage, 70 localities remained on the sub-list, consisting of 3.0 million voters (out of about 3.6 million total voters in the 1,050 localities). Each locality on this sub-list had had more than 10,000 voters in the previous elections (two localities had more than 200,000 voters, 14 localities had 50,000 to 200,000 voters, and 56 localities had 10,000 to 50,000 voters).

\section{Step 2: Deciding on the criteria}

To decide on the criteria, in-depth interviews and focus group discussions were conducted with people who represented the overall political map to discuss the relevant issues. Experts analysed the results and transcripts of these questionnaires, and extracted the criteria from them.

The number of criteria determined in this way depended on the number of characteristics identified through in-depth interviews. We could use the statistical significance of the results to determine their importance. Obviously, it is possible to 
add criteria that were not derived from the in-depth interviews, but rather based on experience or rational judgment.

To determine the criteria in our case, we used data that were collected and analysed by a respected research firm hired by " $Z$ ". The research firm conducted indepth interviews with a representative sample of 1,007 people who answered detailed questionnaires, and led six focus groups consisting of 10-15 people each. The firm's experts, together with members of the party's strategy team, analysed the results of the questionnaires and the transcriptions to extract the criteria from them.

The results of the analysis showed that potential voters for " $Z$ " were young, educated, and earned an average salary. In addition, the analysis found that there was a substantial potential electorate among immigrants from the former Soviet Union who came to Israel during the 1990s. Other characteristics, such as previous political orientation or intensity of religious belief, were not found to be meaningful in this context.

\section{Step 3: Weighting the criteria}

The issue of weighting criteria has been widely discussed in the literature, mainly because this process is strictly dependent on the subjective assessments of decision-makers (Krylovas et al., 2014; Petrovsky, 2001; Saaty, 1977, 1980, 1990; Utkin, 2014). To avoid potential drawbacks, we set weights in two stages. First, we ranked the criteria qualitatively based on the statistical significance levels obtained in the preliminary analysis: the more significant the criterion, the higher it was ranked. Second, we chose the three simple and easy-to-implement weighting techniques that were presented in Barron and Barrett (1996):

a. Equal weights (EW). This is the simplest technique. It is used when the criteria cannot be rated or prioritised, either because of lack of information or because the information indicates that all of the criteria have the same significance. In this case, given $\mathrm{N}$ criteria, the weight of each criterion will be $1 / \mathrm{N}$. For example, in the case of four criteria, the weight of each criterion will be $25 \%$.

b. Rank-sum (RS). In this technique, weights are linearly proportional to their significance rank, and their sum is normalised to 1 . For simplicity, assume that the criteria are arranged in an order that is identical to their importance (i.e., criterion 1 is ranked higher than criterion 2 and so on until the last, least important criterion indexed/N). In such a case, the formula for the weight of the $\mathrm{j}^{\text {th }}$ criterion is:

$$
w_{j}=\frac{2(N-j+1)}{N(N+1)}
$$

In the case of four criteria, their weights would be: $40 \%, 30 \%, 20 \%$, and $10 \%$.

c. Rank-order centroid (ROS). In this technique, weights are computed from the vertices of a simplex and their sum is normalised to 1. As before, the order of the criteria is equal to their importance. The formula for the weight of the $j^{\text {th }}$ criterion is:

$$
w_{j}=\frac{1}{N} \sum_{k=j}^{N} \frac{1}{k}
$$

In the case of four criteria, their weights would be: $52 \%, 27 \%, 14 \%$, and $6 \%$. 
Table 1 lists the four criteria, in descending order of importance, along with their weights using these three techniques.

Table 1: Criteria, criteria definitions, and weights in each technique

\begin{tabular}{|c|c|c|c|c|c|}
\hline$\#$ & Criterion & Definition & EW & RS & ROC \\
\hline $\mathbf{1}$ & Age group & $\begin{array}{c}\text { Rate of people ages 20-34 in } \\
\text { locality }\end{array}$ & 0.25 & 0.4 & 0.52 \\
\hline $\mathbf{2}$ & Country of origin & $\begin{array}{c}\text { Rate of people in the locality } \\
\text { who are immigrants from the } \\
\text { former Soviet Union }\end{array}$ & 0.25 & 0.3 & 0.27 \\
\hline $\mathbf{3}$ & $\begin{array}{c}\text { Educational } \\
\text { level }\end{array}$ & $\begin{array}{c}\text { Rate of highly educated people } \\
\text { in locality }\end{array}$ & 0.25 & 0.2 & 0.15 \\
\hline $\mathbf{4}$ & Income & $\begin{array}{c}\text { Gap, in absolute value, from } \\
\text { average income in locality }\end{array}$ & 0.25 & 0.1 & 0.06 \\
\hline
\end{tabular}

\section{Step 4: Calculating the nominal and} proportional scores

Next, we calculated the nominal scores of the localities based on each criterion. In many cases, the MCDM score matrix was created based on expert evaluations or brainstorming (e.g., pairwise comparison). The complexity of this process, the difficulty of maintaining internal traceability, and the subjectivity inherent are key arguments made by critics against the MCDM method and the AHP process (Asadabadi et al., 2019; Noghin, 2001). However, as we noted in the previous section, these shortcomings are avoided in our case, because the score matrix was objectively calculated using independent external resources. First, we extracted the demographic and socioeconomic data of localities throughout Israel and the information on voting patterns from official Israeli websites (Central Bureau of Statistics, 2018; Results of the 20th Knesset, 2015). We also used other popular public databases (Hovav, 2017; Results of the 2015 Elections, 2019). Second, we normalised these nominal scores by using the revised analytic hierarchy process (Belton and Gear, 1983). A proportional score of the $\mathrm{i}^{\mathrm{t}^{\text {th}}}$-criterion in the $\mathrm{j}^{\text {th }}$-locality is the quotient of the nominal score divided by the maximum score calculated in this criterion, namely:

$$
y_{i j}=\frac{x_{i j}}{\max _{j}\left\{x_{i j}\right\}} \quad i=1,2, \ldots N
$$

where $N$ is the number of criteria, $x_{i j}$ is the nominal score of the $i^{\text {th }}$-criterion in the $\mathrm{j}^{\text {th }}$ locality, and $y_{i j}$ is the relative score of the $\mathrm{i}^{\text {th }}$-criterion in the $\mathrm{j}^{\text {th }}$-locality.

For example, to calculate a locality's score regarding the "age group" criterion, we first obtained the percentage of residents aged 20-34 in each of the 70 localities; the maximum value in this criterion was 28.7 (in the city of Tel AvivJaffa). We then used this value to calculate the proportional scores of all 70 localities according to Equation 3, to get their 
proportional scores. Thus, the nominal score of Acre (24.9) was normalised to $0.87(=24.9 / 28.7)$, the nominal score of Afula (22.3) was normalised to 0.78 , and so on. We repeated the same process for all criteria, to get normalised scores. The list of nominal and normalised scores of the 70 localities is found in Table A.1 in the appendix.

\section{Step 5: Arriving at a single score for each locality and ranking localities}

The last step was to calculate the final scores of the localities. Various models are available for aggregating the multi-criteria weights and scores of alternatives into a single score. In our study, we used the classic and popular weighted sum (WS) model. According to this model, the final grade of an alternative is obtained by multiplying the grades for each criterion by the weight of the criteria, namely:

$$
\text { Final_Score }(j)=\sum_{i=1}^{N} w_{i} y_{i j} \forall j
$$

Table 2 lists the top 10 localities using each weighting method.

Table 2: Ranking obtained through each weighting method

\begin{tabular}{|c|c|c|c|c|c|c|}
\hline \multirow{2}{*}{ Rank } & \multicolumn{2}{|c|}{ EW } & \multicolumn{2}{c|}{ RS } & \multicolumn{2}{c|}{ ROC } \\
\cline { 2 - 7 } & $\begin{array}{c}\text { Name of } \\
\text { locality }\end{array}$ & Score & $\begin{array}{c}\text { Name of } \\
\text { locality }\end{array}$ & Score & $\begin{array}{c}\text { Name of } \\
\text { locality }\end{array}$ & Score \\
\hline $\mathbf{1}$ & Ariel & $82.8 \%$ & Ariel & $86.7 \%$ & Ariel & $90.0 \%$ \\
\hline $\mathbf{2}$ & Haifa & $80.5 \%$ & Haifa & $80.0 \%$ & Haifa & $82.4 \%$ \\
\hline $\mathbf{3}$ & Nesher & $79.1 \%$ & Nazareth Illit & $78.2 \%$ & Nazareth Illit & $79.7 \%$ \\
\hline $\mathbf{4}$ & Carmiel & $75.0 \%$ & Nesher & $76.0 \%$ & Tel Aviv Jaffa & $78.8 \%$ \\
\hline $\mathbf{5}$ & Nazareth Illit & $74.9 \%$ & Tel Aviv- Jaffa & $75.1 \%$ & Sderot & $75.7 \%$ \\
\hline $\mathbf{6}$ & Tel Aviv-Jaffa & $74.6 \%$ & Carmiel & $74.1 \%$ & Nesher & $75.6 \%$ \\
\hline $\mathbf{7}$ & Maalot- & $70.8 \%$ & Maalot- & $72.5 \%$ & Maalot- & $74.5 \%$ \\
& Tarshiha & & Tarshiha & & Tarshiha & \\
\hline $\mathbf{8}$ & Beer Sheva & $69.6 \%$ & Arad & $71.3 \%$ & Carmiel & $73.5 \%$ \\
\hline $\mathbf{9}$ & Arad & $69.3 \%$ & Sderot & $70.6 \%$ & Arad & $72.6 \%$ \\
\hline $\mathbf{1 0}$ & Ashkelon & $68.7 \%$ & Kiryat Yam & $69.7 \%$ & Beer Sheva & $70.7 \%$ \\
\hline
\end{tabular}

It can be seen from the table that the same eight localities were ranked in the top ten of the three methods, and that only twelve localities were ranked in all three methods. Thus, we recommended that the party's strategic team focus its efforts on

these twelve localities. The full scores and rankings are listed in Table A.2 in the appendix.

\section{Results}


The elections were held on 9 April 2019. None of the new parties that competed reached the $3.25 \%$ threshold required to obtain a seat in the Knesset. " $Z$ " received $2.74 \%$ of the votes; only one other new party received more votes (3.22\%, which was also below the threshold) (Results of the 21st Knesset, 2019). There are several explanations for this failure, all of them based on the fact that voting patterns depend on many variables, some of which arise only a few days or a few hours before election day-or even during election day. Nevertheless, it should be noted that " $Z$ " started its campaign with the support of only $0.4 \%$ of voters but ended the election with $2.74 \%$ of the votes.

Analysis of the results revealed that " $Z$ " received more than $3.25 \%$ of the votes in 20 of the 70 localities on our sub-list, and more than $2.74 \%$ of the votes in 47 of the localities. In our focused list, the party gained much better results: 8 and 13, respectively.

Table 3. Number of localities that gave " $Z$ " more than the required threshold of votes and more than average votes

\begin{tabular}{|c|c|c|}
\hline Number of localities & 70 & 15 \\
\hline Vote percentage $>\mathbf{3 . 2 5 \%}$ & 20 & 8 \\
\hline Vote percentage $\mathbf{>} \mathbf{2 . 7 4 \%}$ & 47 & 13 \\
\hline
\end{tabular}

This outcome is particularly striking when considering that, as a new party, " $Z$ " had no core of voters or previous empirical data on which to base decisions about how to allocate its resources for maximum effect. Thus, the model provides a simple, valid tool for making data-driven decisions about allocating resources that can be easily updated for future election campaigns.

\section{Discussion}

In this article, we present a model based on multi-criteria decision making for allocating funding during elections. The novelty of the present method lies in its use of the revised analytic hierarchy process in the context of political campaigns and use of input data that combines information from a confidential dataset and public databases. Furthermore, both the weighting techniques and weighted-sum model are characterised by their simplicity and clarity. Thus, campaign managers can easily follow the model's rationale. Using only basic mathematical tools, they can tweak the model to determine how changing the preferred criteria impact the original results.

The transparency of the suggested methodology is a valuable advantage for campaign managers. Given the enormous pressure that they face during campaigns, a simple, user-friendly dynamic tool that helps them make unbiased decisions about how budget allocation may be very useful for them. 
The method is particularly relevant for small and/or new parties that have no established voter base and no previous data with which to make decisions about allocating their limited resources to achieve the best results. Comparisons of various methods for weighting criteria demonstrated that the RS and ROS techniques produced results that were closest to the actual outcomes of the election. Although the model is applicable to all parties in general, it is more relevant and even urgent for new parties, due to the extra obstacles they must overcome: the absence of a steady core of loyal constituents, the lack of proven political achievements, and the non-existence of federal funding. We maintain that our model can help new parties cope with these challenges by directing their budgets efficiently and rationally.
One can argue that a model for resource allocation should address expectations about the spending behaviour of competitors or, at the very least, consider how variations among competitors affect the strengths and weaknesses of the current model. Although it is outside the scope of our research, future studies can include consideration of this factor when analysing expenditure decisions made during political campaigns, such as responses to the behaviour of competitors and advertising on traditional media versus on social networks. Furthermore, future research can make additional refinements, such as by identifying the voting patterns of neighbourhoods or mixed localities, and by building a more focused and effective map of priorities when allocating campaign budgets. In addition, given actual elections results, different weighting techniques and/or criteria combinations may be tested to improve the model's performance.

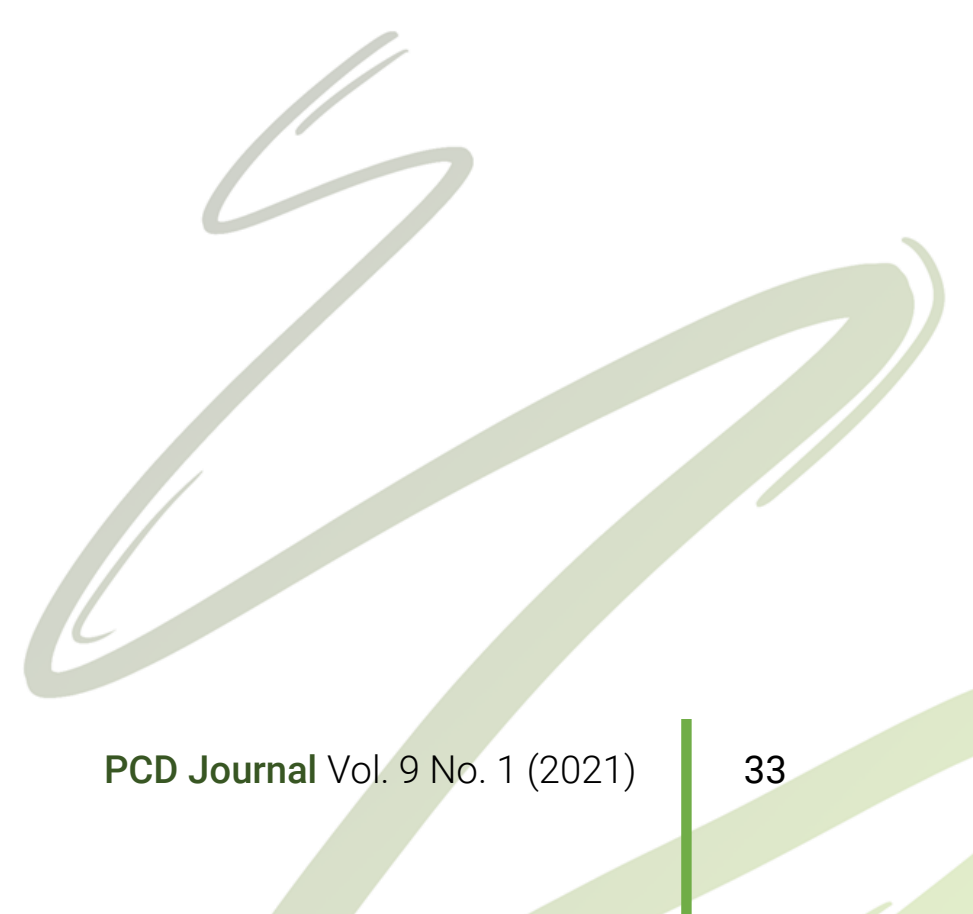




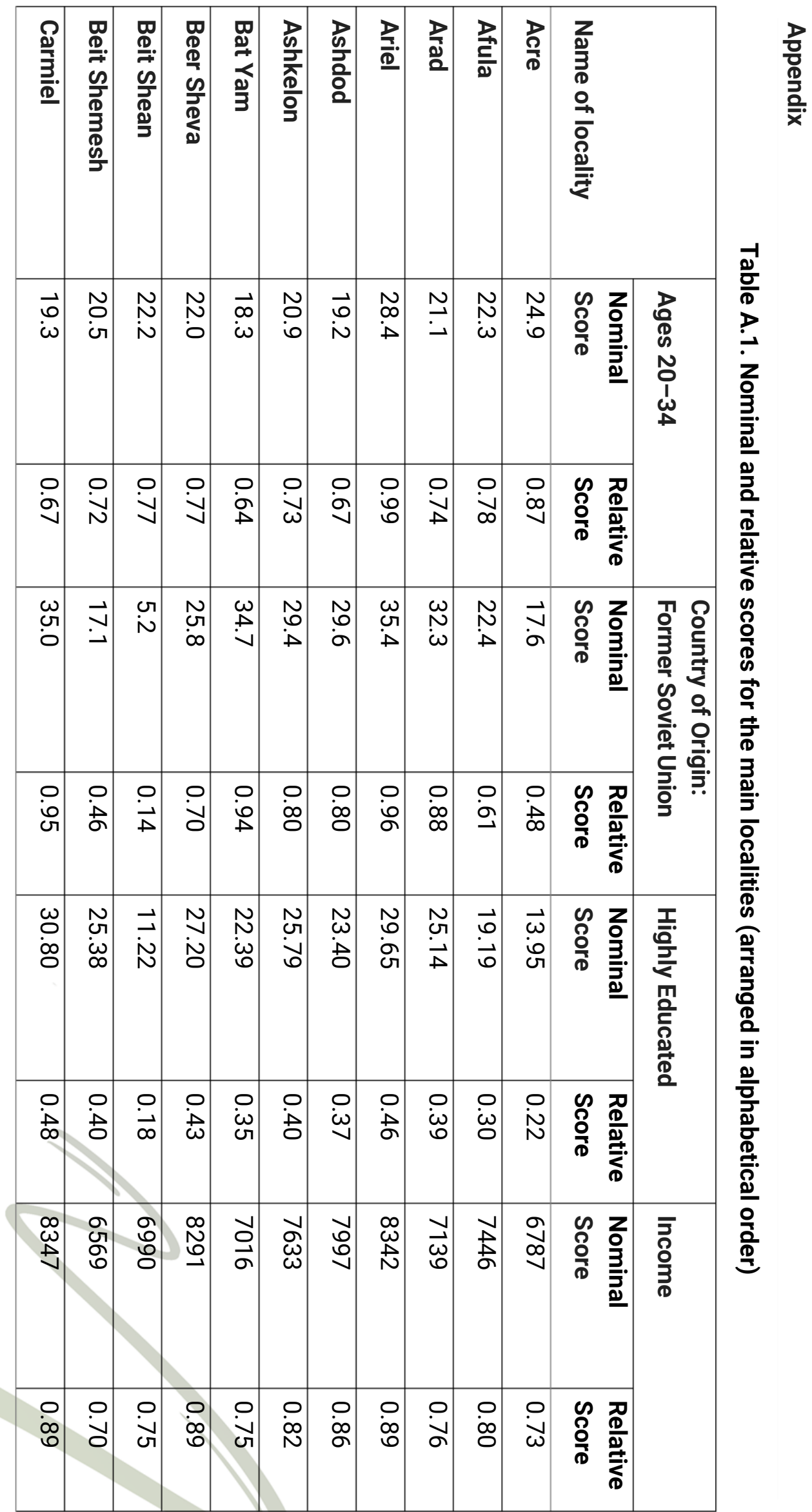




\begin{tabular}{|c|c|c|c|c|c|c|c|c|c|c|c|c|c|c|c|}
\hline 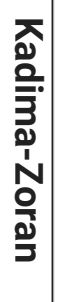 & 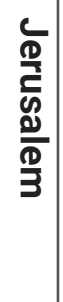 & $\frac{\mathrm{T}}{\mathrm{O}}$ & 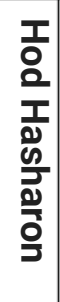 & $\frac{\substack{\mathbf{D} \\
\mathbf{N}}}{\text { \} }} &{\begin{array}{l}\frac{\mathbf{T}}{\mathbf{D}} \\
\overrightarrow{\vec{D}}\end{array}} &{\begin{array}{l}\frac{1}{0} \\
\frac{0}{0} \\
\frac{0}{d}\end{array}} &{\text { 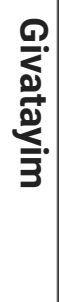 }} &{\text { 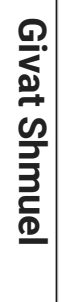 }} &{\begin{array}{l}\mathbb{Q} \\
\mathbb{D} \\
\frac{0}{\mathbb{D}} \\
\mathbb{D}\end{array}} &{\text { 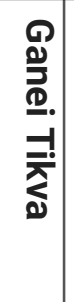 }} &{\text { 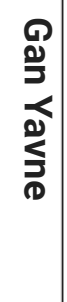 }} &{\stackrel{\text { 圁 }}{\stackrel{2}{9}}} &{\text { 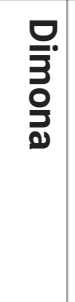 }} &{\text { 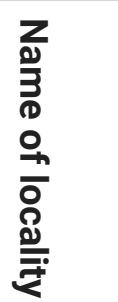 }} &{ } \\
{\hline \vec{\omega}} &{\begin{array}{l}\hat{\omega} \\
\sigma \\
\sigma\end{array}} &{\begin{array}{l}\vec{\infty} \\
\dot{\omega}\end{array}} &{\begin{array}{l}\vec{a} \\
\dot{\sigma}\end{array}} &{\begin{array}{l}\vec{\infty} \\
\dot{\omega}\end{array}} &{\begin{array}{l}N \\
\dot{\omega}\end{array}} &{\begin{array}{l}\text { ○ } \\
\dot{\omega}\end{array}} &{\stackrel{N}{\circ}} &{\begin{array}{l}\overrightarrow{0} \\
0\end{array}} &{\begin{array}{l}\vec{ज} \\
\vec{\Delta}\end{array}} &{\overrightarrow{\overrightarrow{0}}} &{\vec{\infty}} &{\stackrel{N}{+}} &{\stackrel{\sim}{\sim}} &{\text { 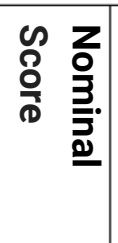 }} &{\begin{array}{l}\text { D } \\
\text { D } \\
0 \\
N \\
0 \\
1 \\
\omega \\
\qquad\end{array}} \\
{\hline \begin{array}{l}0 \\
\text { ò }\end{array}} &{\begin{array}{l}0 \\
0 \\
N \\
\text { D. }\end{array}} &{\begin{array}{l}\text { O } \\
\dot{\phi} \\
\dot{\phi}\end{array}} &{\begin{array}{l}0 \\
\text { 心) } \\
\infty\end{array}} &{\begin{array}{l}\circ \\
\dot{\rho} \\
\dot{\phi}\end{array}} &{\begin{array}{l}0 \\
\dot{0} \\
\text { v }\end{array}} &{\stackrel{\circ}{\beth}} &{\stackrel{O}{N}} &{\begin{array}{l}\text { o } \\
\text { बे }\end{array}} &{\begin{array}{l}O \\
\dot{\Delta} \\
\not\end{array}} &{\text { O }} &{\begin{array}{l}0 \\
\text { oे } \\
\omega\end{array}} &{\begin{array}{l}0 \\
0 \\
\text { जo }\end{array}} &{\stackrel{O}{v}} &{\text { 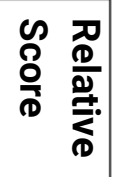 }} &{ } \\
{\hline \vec{\omega}} &{\begin{array}{l}\infty \\
\dot{N}\end{array}} &{\overrightarrow{0}} &{\stackrel{a}{v}} &{\underset{\infty}{\vec{\infty}}} &{\begin{array}{l}N \\
\omega \\
\Delta\end{array}} &{\stackrel{N}{\underset{-}{ \pm}}} &{\text { 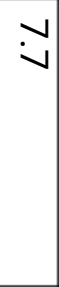 }} &{\begin{array}{l}0 \\
\end{array}} &{\begin{array}{l}\infty \\
\infty\end{array}} &{\vec{i}} &{\begin{array}{l}0 \\
0\end{array}} &{\frac{N}{\dot{\omega}}} &{\vec{a}} &{\text { 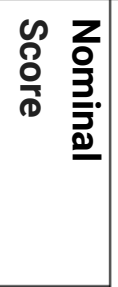 }} &{\text { 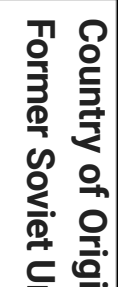 }} \\
{\hline \begin{array}{l}\stackrel{0}{ } \\
\stackrel{\mathrm{N}}{0}\end{array}} &{\begin{array}{l}\stackrel{0}{ } \\
\stackrel{N}{N}\end{array}} &{\begin{array}{l}\text { ㅇ } \\
\text { aे }\end{array}} &{\stackrel{\circ}{\infty}} &{\stackrel{\circ}{\dot{\omega}}} &{\text { 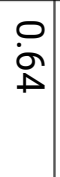 }} &{\begin{array}{l}0 \\
\text { ò } \\
\text { vo }\end{array}} &{\stackrel{\circ}{\text { N }}} &{\begin{array}{l}0 \\
\text { Na }\end{array}} &{\stackrel{\circ}{\stackrel{O}{\Delta}}} &{\stackrel{0}{\vec{\omega}}} &{\stackrel{\stackrel{O}{N}}{\Delta}} &{\begin{array}{l}0 \\
\text { ज্ } \\
\end{array}} &{\begin{array}{l}\text { Oे } \\
\text { जे }\end{array}} &{\text { 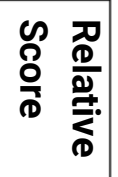 }} &{\text { 릉. }} \\
{\hline \begin{array}{l}\stackrel{p}{\infty} \\
\underset{0}{0}\end{array}} &{\begin{array}{l}N \\
\text { ò } \\
\sigma\end{array}} &{\begin{array}{l}\text { N } \\
\text { io } \\
\infty\end{array}} &{\begin{array}{l}\sigma \\
\omega \\
\sim\end{array}} &{\begin{array}{l} \pm \\
N\end{array}} &{\begin{array}{l}\vec{N} \\
\stackrel{N}{V}\end{array}} &{\begin{array}{l}N \\
\text { ज } \\
\Delta \\
\text { जा }\end{array}} &{\begin{array}{l}\text { ç } \\
\text { og }\end{array}} &{\begin{array}{l}a \\
\overrightarrow{0} \\
\overrightarrow{0}\end{array}} &{\begin{array}{l}\omega \\
\tilde{v} \\
\text { N }\end{array}} &{\begin{array}{l}\overrightarrow{0} \\
\dot{0} \\
\vec{p}\end{array}} &{\begin{array}{l}\omega \\
\stackrel{\omega}{ } \\
\omega \\
\Delta\end{array}} &{\begin{array}{l}\vec{a} \\
\underset{\omega}{\omega}\end{array}} &{\begin{array}{l}\overrightarrow{\mathrm{N}} \\
\dot{\Delta}\end{array}} &{\text { 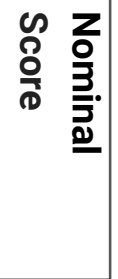 }} &{\text { 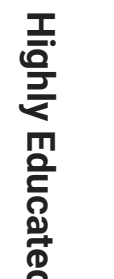 }} \\
{\hline \stackrel{\circ}{\circ}} &{\begin{array}{l}\circ \\
\dot{\omega}\end{array}} &{\stackrel{\circ}{\ominus}} &{\begin{array}{l}0 \\
\infty \\
\infty \\
1\end{array}} &{\stackrel{O}{\perp}} &{\begin{array}{l}\text { ㅇ } \\
\text { gे }\end{array}} &{\begin{array}{l}0 \\
\dot{0} \\
0\end{array}} &{\begin{array}{l}0 \\
\dot{0} \\
\omega\end{array}} &{\begin{array}{l}0 \\
\text { ŏ }\end{array}} &{\begin{array}{l}0 \\
\text { or } \\
\mathrm{r}\end{array}} &{\stackrel{\circ}{y}} &{\begin{array}{l}\stackrel{0}{1} \\
\stackrel{\infty}{\infty}\end{array}} &{\begin{array}{l}\circ \\
\dot{N} \\
\text { N }\end{array}} &{\stackrel{\circ}{\stackrel{0}{\infty}}} &{\text { 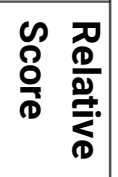 }} &{ } \\
{\hline \begin{array}{l}\vec{N} \\
\vec{\omega} \\
\vec{\sigma}\end{array}} &{\begin{array}{l}Y \\
\overrightarrow{0}\end{array}} &{\begin{array}{l}\infty \\
\stackrel{0}{\circ} \\
\text { ᄋ̆ }\end{array}} &{\begin{array}{l}\vec{\omega} \\
\vec{v}\end{array}} &{\begin{array}{l}\overrightarrow{\vec{v}} \\
\text { N }\end{array}} &{\text { 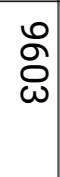 }} &{\begin{array}{l}\infty \\
\text { N్} \\
V\end{array}} &{\begin{array}{l}\vec{N} \\
\text { No }\end{array}} &{\begin{array}{l}\vec{N} \\
\pm \\
0\end{array}} &{\begin{array}{l}\overrightarrow{\vec{A}} \\
\text { مे }\end{array}} &{\begin{array}{l}\vec{\omega} \\
\vec{\omega} \\
\tilde{\sigma}\end{array}} &{\begin{array}{l}\overrightarrow{0} \\
\stackrel{0}{\omega} \\
\vec{\omega}\end{array}} &{\text { 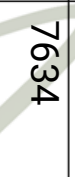 }} &{\begin{array}{l}0 \\
N \\
N\end{array}} &{\text { 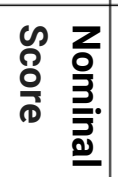 }} &{\begin{array}{l}\overline{\bar{n}} \\
\stackrel{0}{3} \\
\overline{0}\end{array}} \\
{\hline \begin{array}{l}0 \\
\circ \\
\infty\end{array}} &{\text { 이 }} &{\begin{array}{l}\circ \\
\stackrel{\circ}{\not}\end{array}} &{\begin{array}{l}\text { ㅇ } \\
\text { जु }\end{array}} &{\text { 이 }} &{\begin{array}{l}0 \\
\dot{0} \\
\dot{0}\end{array}} &{\begin{array}{l}0 \\
0 \\
0 \\
0\end{array}} &{\begin{array}{l}\text { 잉 } \\
\text { g̊ }\end{array}} &{\text { के }} &{\stackrel{ }{ }} &{\begin{array}{l}\circ \\
\text { जू }\end{array}} &{\begin{array}{l}\text { ○ } \\
\stackrel{\infty}{\omega} \\
\omega\end{array}} &{\begin{array}{l}0 \\
0 \\
N \\
N\end{array}} &{\begin{array}{l}0 \\
\infty \\
\infty \\
\infty\end{array}} &{\text { 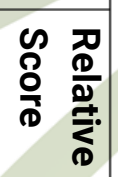 }} &{ } \\
$\hline
\end{tabular}




\begin{tabular}{|c|c|c|c|c|c|c|c|c|c|c|c|c|c|c|c|}
\hline 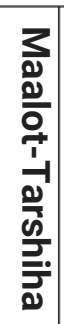 & $\begin{array}{l}3 \\
\frac{3}{0-} \\
\frac{0}{0} \\
\frac{1}{2} \\
\frac{0}{3} \\
3 \\
3\end{array}$ & 5 & 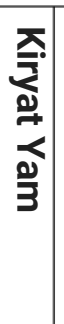 & 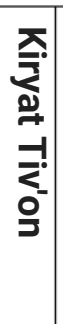 & 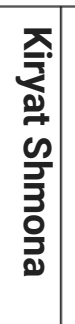 & 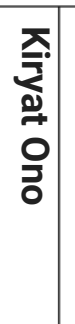 & 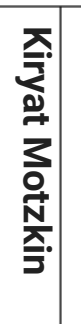 & 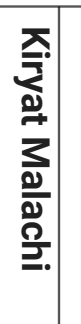 & 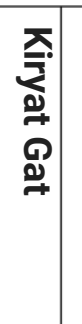 & 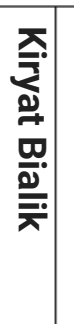 & 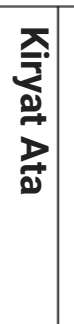 & 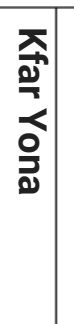 & 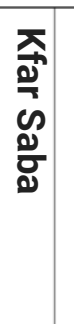 & 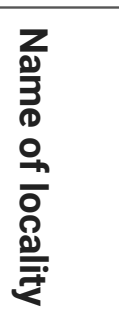 & \\
\hline $\begin{array}{l}N \\
N \\
\sigma\end{array}$ & $\frac{N}{\vec{G}}$ & $\frac{N}{\overrightarrow{0}}$ & $\begin{array}{l}\vec{\infty} \\
\infty\end{array}$ & $\vec{a}$ & $\begin{array}{c}\underset{\omega}{N} \\
\infty\end{array}$ & $\begin{array}{l}\overrightarrow{+} \\
\infty\end{array}$ & $\begin{array}{l}\vec{\infty} \\
\dot{\omega}\end{array}$ & $\begin{array}{l}N \\
\mathcal{N} \\
\dot{v}\end{array}$ & 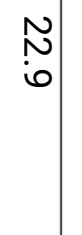 & $\begin{array}{l}\overrightarrow{0} \\
\dot{\sigma}\end{array}$ & $\begin{array}{l}\text { No } \\
\text { ă }\end{array}$ & $\begin{array}{l}\overrightarrow{0} \\
0 \\
0\end{array}$ & $\vec{a}$ & 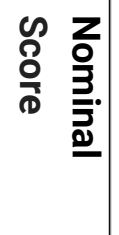 & $\begin{array}{l}\vec{D} \\
\text { D } \\
\mathbb{D} \\
N \\
0 \\
1 \\
\omega \\
\mathbb{D}\end{array}$ \\
\hline$\stackrel{\circ}{\text { ปै }}$ & $\stackrel{O}{v}$ & $\stackrel{\circ}{\circ}$ & $\begin{array}{l}\text { O } \\
\text { ò } \\
\text { v }\end{array}$ & $\begin{array}{l}\circ \\
\text { ू }\end{array}$ & 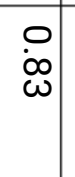 & 옴 & $\begin{array}{l}\circ \\
\circ \\
\dot{\phi}\end{array}$ & $\begin{array}{l}0 \\
0 \\
0\end{array}$ & $\begin{array}{l}0 \\
\text { o } \\
0\end{array}$ & $\begin{array}{l}0 \\
\text { ò } \\
\text { ज. }\end{array}$ & $\stackrel{0}{N}$ & $\begin{array}{l}\text { ○ } \\
\text { ळे }\end{array}$ & $\begin{array}{l}0 \\
\text { 의 }\end{array}$ & 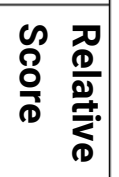 & \\
\hline $\begin{array}{l}\omega \\
\text { Oे } \\
0\end{array}$ & $\overrightarrow{\vec{D}}$ & $\stackrel{N}{\stackrel{N}{D}}$ & $\begin{array}{l}\omega \\
\omega \\
\omega \\
\omega\end{array}$ & $\begin{array}{c}c \\
\omega\end{array}$ & $\overrightarrow{\vec{u}}$ & $\begin{array}{l}9 \\
0\end{array}$ & $\begin{array}{l}N \\
\stackrel{N}{N}\end{array}$ & $\vec{v}$ & $\stackrel{N}{+}$ & $\begin{array}{l}N \\
\stackrel{a}{a}\end{array}$ & $\vec{\Delta}$ & $\begin{array}{l}\infty \\
\sigma\end{array}$ & $\overrightarrow{\overrightarrow{0}}$ & 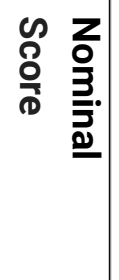 & 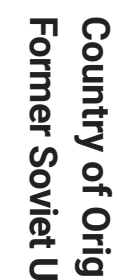 \\
\hline $\begin{array}{l}0 \\
\infty \\
\infty \\
\not\end{array}$ & $\begin{array}{l}\circ \\
\stackrel{+}{N}\end{array}$ & $\begin{array}{l}0 \\
\text { ஸा } \\
\infty\end{array}$ & $\begin{array}{l}\text { 이 } \\
\text { वे }\end{array}$ & $\stackrel{\circ}{\vec{\Delta}}$ & $\begin{array}{l}\circ \\
\stackrel{0}{ \pm}\end{array}$ & $\stackrel{\circ}{\overrightarrow{0}}$ & $\begin{array}{l}\circ \\
\text { aे }\end{array}$ & $\begin{array}{l}\stackrel{0}{\vec{\omega}} \\
\stackrel{\vec{\omega}}{ }\end{array}$ & $\begin{array}{l}\text { Oे } \\
\text { जे }\end{array}$ & $\begin{array}{l}\circ \\
\text { ํㅣ }\end{array}$ & $\begin{array}{l}0 \\
\stackrel{v}{*}\end{array}$ & $\stackrel{\circ}{\stackrel{\omega}{\omega}}$ & $\stackrel{\circ}{\dot{\omega}}$ & 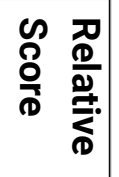 & 름 \\
\hline $\begin{array}{c}N \\
\omega \\
\infty \\
\infty \\
\infty\end{array}$ & $\begin{array}{l}\text { No } \\
\text { \&̊ }\end{array}$ & $\begin{array}{l}\vec{v} \\
0 \\
\infty\end{array}$ & $\begin{array}{l}N \\
\dot{v} \\
v\end{array}$ & $\underset{0}{\tilde{0}}$ & $\begin{array}{l}\vec{\sigma} \\
\infty \\
\phi \\
\phi\end{array}$ & $\begin{array}{l}\vec{a} \\
\text { Sे }\end{array}$ & 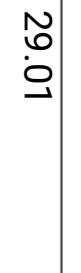 & $\begin{array}{l}\overrightarrow{0} \\
\text { o } \\
o\end{array}$ & $\overrightarrow{\vec{v}}$ & $\begin{array}{l}\text { vy } \\
\text { ô } \\
\text { v }\end{array}$ & 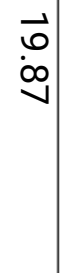 & $\begin{array}{l}0 \\
. \\
\infty \\
\infty\end{array}$ & $\begin{array}{l}\text { जे } \\
\dot{N} \\
\text { ज }\end{array}$ & 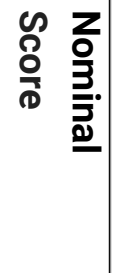 & 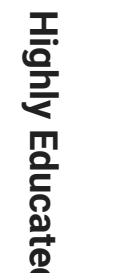 \\
\hline$\stackrel{\circ}{\dot{\omega}}$ & $\begin{array}{l}\circ \\
\stackrel{D}{ \pm}\end{array}$ & $\begin{array}{l}\circ \\
\stackrel{0}{N}\end{array}$ & 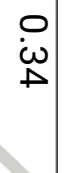 & $\begin{array}{l}0 \\
\infty \\
-\infty\end{array}$ & $\begin{array}{l}\text { ㅇ. } \\
\text { Na }\end{array}$ & $\stackrel{\circ}{\omega}$ & 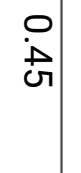 & $\stackrel{\circ}{\stackrel{\circ}{v}}$ & $\begin{array}{l}\text { ㅇ } \\
\text { Na }\end{array}$ & $\stackrel{\circ}{\stackrel{े}{+}}$ & $\stackrel{\circ}{\dot{\omega}}$ & $\begin{array}{l}0 \\
\circ \\
\stackrel{\phi}{a}\end{array}$ & $\stackrel{o}{y}$ & 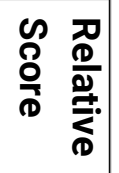 & \\
\hline $\begin{array}{l}\text { V } \\
\text { ज }\end{array}$ & $\begin{array}{l}\infty \\
\stackrel{0}{ } \\
\omega \\
\sigma\end{array}$ & $\begin{array}{l}\hat{\sigma} \\
\stackrel{b}{\omega}\end{array}$ & 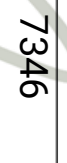 & $\begin{array}{l}\vec{N} \\
\vec{v}\end{array}$ & $\stackrel{N}{N}$ & $\begin{array}{l}\vec{\omega} \\
\stackrel{\sigma}{\perp} \\
\end{array}$ & 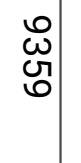 & $\begin{array}{l}\stackrel{\circ}{\circ} \\
\stackrel{\circ}{\infty}\end{array}$ & ঐ̆ & $\begin{array}{l}\infty \\
\infty \\
\stackrel{1}{\omega}\end{array}$ & $\begin{array}{l}\infty \\
\stackrel{\omega}{\omega} \\
\stackrel{\infty}{0}\end{array}$ & $\begin{array}{l}\overrightarrow{0} \\
\text { O } \\
\end{array}$ & $\begin{array}{l}\vec{\Xi} \\
\vec{U}\end{array}$ & 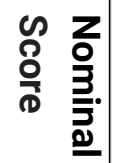 & $\begin{array}{l}\bar{\Xi} \\
\stackrel{0}{0} \\
\bar{\emptyset}\end{array}$ \\
\hline $\begin{array}{l}0 \\
\infty \\
\infty \\
\omega\end{array}$ & ஷ̊ & $\stackrel{O}{\Delta}$ & $\stackrel{\circ}{0}$ & $\stackrel{\circ}{\stackrel{0}{0}}$ & $\stackrel{\bigcirc}{\searrow}$ & $\begin{array}{l}O \\
\text { in } \\
\perp\end{array}$ & $\overrightarrow{8}$ & $\begin{array}{l}0 \\
\dot{\phi} \\
\dot{\phi}\end{array}$ & $\stackrel{\circ}{y}$ & $\begin{array}{l}0 \\
\dot{0} \\
\text { जा }\end{array}$ & $\begin{array}{l}0 \\
0 \\
0 \\
0\end{array}$ & $\begin{array}{l}0 \\
\stackrel{\infty}{v}\end{array}$ & $\stackrel{\circ}{\perp}$ & 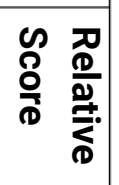 & \\
\hline
\end{tabular}




\begin{tabular}{|c|c|c|c|c|c|c|c|c|c|c|c|c|c|c|c|}
\hline 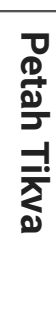 & 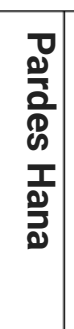 & 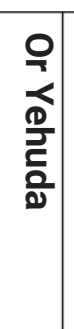 & 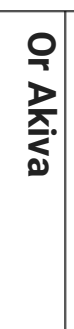 & 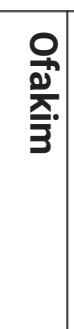 & 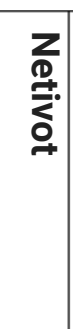 & 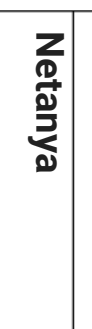 & $\begin{array}{l}\mathbf{z} \\
\mathbf{D} \\
\hat{D} \\
\mathbf{N} \\
\overline{0} \\
\overline{0}\end{array}$ & $\begin{array}{l}\mathbf{z} \\
\mathbf{0} \\
\underline{\underline{p}} \\
\overline{\mathbf{D}} \\
\mathbf{q}\end{array}$ & 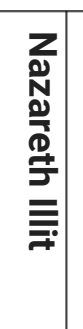 & & 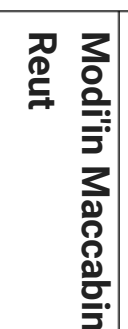 & 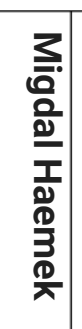 & 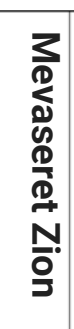 & 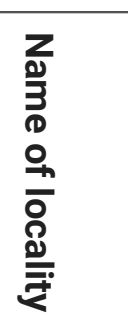 & \\
\hline$\vec{v}$ & $\begin{array}{l}\vec{v} \\
0\end{array}$ & $\stackrel{N}{\sim}$ & $\stackrel{N}{\vec{N}}$ & $\begin{array}{c}N \\
\stackrel{\infty}{\infty}\end{array}$ & $\begin{array}{l}N \\
N \\
0\end{array}$ & $\begin{array}{l}\vec{\infty} \\
\dot{v}\end{array}$ & $\vec{c}$ & $\stackrel{\vec{N}}{\vec{a}}$ & $\begin{array}{l}N \\
\tilde{N} \\
0\end{array}$ & $\begin{array}{l}\vec{\infty} \\
\dot{N}\end{array}$ & $\begin{array}{l}\vec{\infty} \\
0 \\
0\end{array}$ & $\stackrel{N}{\sim}$ & $\begin{array}{l}N \\
\infty \\
\infty\end{array}$ & 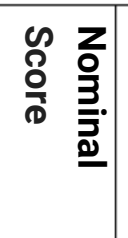 & 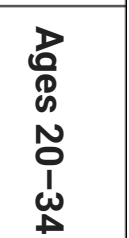 \\
\hline ò & 잉 & పे & $\stackrel{D}{D}$ & $\begin{array}{l}0 \\
\text { o } \\
\text { o }\end{array}$ & $\begin{array}{l}\stackrel{0}{\circ} \\
: 0 \\
0\end{array}$ & $\begin{array}{l}\text { Oे } \\
\text { ồ }\end{array}$ & $\begin{array}{l}0 \\
\text { i⿱ } \\
N\end{array}$ & نे & $\begin{array}{l}0 \\
\dot{0}\end{array}$ & 吕 & 으 & $\stackrel{\circ}{\ominus}$ & 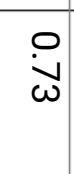 & 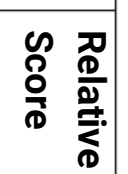 & \\
\hline $\begin{array}{l}\vec{\infty} \\
\infty\end{array}$ & $\begin{array}{l}\vec{N} \\
\mathfrak{u}\end{array}$ & $\begin{array}{l}\overrightarrow{+} \\
\omega\end{array}$ & $\begin{array}{l}N \\
0 \\
\infty\end{array}$ & $\begin{array}{l}N \\
\stackrel{O}{N}\end{array}$ & $\underset{\infty}{\vec{\infty}}$ & Ni & aे & $\begin{array}{l}N \\
\infty \\
0\end{array}$ & $\begin{array}{c}\omega \\
\omega \\
\infty\end{array}$ & $\begin{array}{l}N \\
\end{array}$ & $\begin{array}{l}\overrightarrow{0} \\
\text { or }\end{array}$ & $\begin{array}{l}N \\
\dot{v} \\
\dot{v}\end{array}$ & $\stackrel{0}{N}$ & 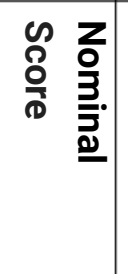 & 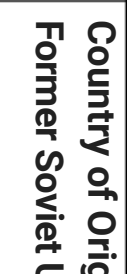 \\
\hline$\stackrel{\circ}{\mathcal{G}}$ & $\stackrel{\stackrel{O}{\omega}}{\stackrel{\omega}{\Delta}}$ & $\begin{array}{l}0 \\
\dot{\omega} \\
\dot{\omega}\end{array}$ & $\begin{array}{l}0 \\
\stackrel{0}{-\infty} \\
\stackrel{1}{2}\end{array}$ & $\begin{array}{l}0 \\
\text { iv } \\
\text { जu }\end{array}$ & 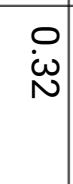 & ज्ञ & $\begin{array}{c}\stackrel{0}{\infty} \\
\stackrel{\infty}{n}\end{array}$ & 이 & $\overrightarrow{\dot{\theta}}$ & 업 & $\stackrel{0}{\text { Uి }}$ & Oे & $\begin{array}{l}\text { O } \\
\text { vin }\end{array}$ & 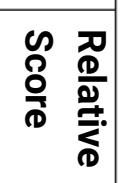 & 흥. \\
\hline $\begin{array}{l}\omega \\
\sigma \\
\sigma\end{array}$ & $\begin{array}{c}\underset{\omega}{\omega} \\
\stackrel{\omega}{\infty} \\
\infty\end{array}$ & $\begin{array}{l}\vec{v} \\
\vec{v}\end{array}$ & $\begin{array}{l}\vec{\infty} \\
\dot{\omega} \\
\dot{v}\end{array}$ & $\begin{array}{c}\overrightarrow{\vec{\Delta}} \\
\overrightarrow{\vec{v}}\end{array}$ & $\begin{array}{l}\vec{c} \\
\dot{\infty}\end{array}$ & $\begin{array}{l}\mathbf{N} \\
\mathbf{N} \\
\mathbf{N}\end{array}$ & $\begin{array}{l}\omega \\
\sigma \\
0 \\
0 \\
\sigma\end{array}$ & $\begin{array}{l}\hat{1} \\
\stackrel{0}{0}\end{array}$ & $\begin{array}{l}N \\
N \\
i \\
N\end{array}$ & $\begin{array}{l}N \\
\infty \\
i \\
0 \\
v\end{array}$ & $\begin{array}{l}\text { y } \\
i \\
\infty\end{array}$ & $\begin{array}{l}N \\
O \\
\dot{\infty} \\
\infty\end{array}$ & $\begin{array}{l}\overrightarrow{0} \\
\dot{\omega}\end{array}$ & 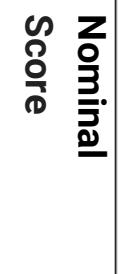 & 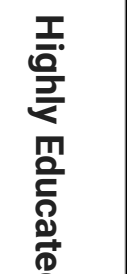 \\
\hline 응 & 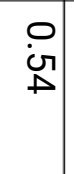 & $\begin{array}{l}0 \\
\text { N }\end{array}$ & $\begin{array}{l}0 \\
\hat{U}\end{array}$ & $\stackrel{\circ}{\vec{v}}$ & $\begin{array}{l}0 \\
\text { Nu }\end{array}$ & $\begin{array}{l}\text { : } \\
\text { aे }\end{array}$ & $\begin{array}{l}0 \\
\text { ज. } \\
\infty\end{array}$ & $\begin{array}{l}0 \\
\text { ò }\end{array}$ & $\begin{array}{l}\stackrel{0}{ } \\
\vec{D}\end{array}$ & $\begin{array}{l}\text { P } \\
\text { जे }\end{array}$ & ن & $\begin{array}{l}0 \\
\dot{\omega} \\
\stackrel{N}{N}\end{array}$ & 眎 & 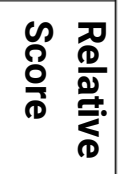 & \\
\hline $\begin{array}{l}\stackrel{\circ}{\circ} \\
\stackrel{0}{0}\end{array}$ & $\frac{\overrightarrow{\mathrm{D}}}{\omega}$ & $\begin{array}{l}D \\
D \\
N\end{array}$ & $\begin{array}{l}\vec{v} \\
\vec{v}\end{array}$ & $\begin{array}{l}0 \\
\hat{\tilde{v}} \\
\mathrm{v}\end{array}$ & $\underset{\stackrel{\omega}{\omega}}{\vec{D}}$ & $\begin{array}{l}\stackrel{0}{N} \\
\mathbb{N}\end{array}$ & $\begin{array}{l}\vec{N} \\
\stackrel{\infty}{\vec{D}} \\
\vec{D}\end{array}$ & $\begin{array}{l}0 \\
\stackrel{0}{0} \\
\omega\end{array}$ & $\begin{array}{l}\text { ㅁ } \\
\text { a }\end{array}$ & \begin{tabular}{l}
0 \\
\multirow{2}{\sigma}{}
\end{tabular} & & $\begin{array}{l}a \\
\stackrel{\omega}{\omega} \\
-\end{array}$ & $\begin{array}{l}\overrightarrow{\vec{v}} \\
\stackrel{\mathrm{D}}{\mathrm{B}}\end{array}$ & 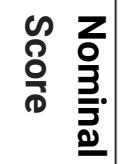 & $\begin{array}{l}\bar{\partial} \\
\stackrel{\partial}{\bar{\partial}} \\
\overline{0}\end{array}$ \\
\hline $\begin{array}{l}\circ \\
\stackrel{\circ}{\circ}\end{array}$ & $\begin{array}{l}0 \\
\dot{0} \\
\omega\end{array}$ & $\begin{array}{l}0 \\
0 \\
\infty \\
\oplus\end{array}$ & ఫે & $\begin{array}{l}0 \\
\dot{\sigma}\end{array}$ & $\begin{array}{l}0 \\
\text { Oे } \\
\infty\end{array}$ & $\begin{array}{l}0 \\
\text { o } \\
0\end{array}$ & $\begin{array}{l}0 \\
\dot{\omega}\end{array}$ & $\begin{array}{l}0 \\
: \\
:\end{array}$ & वे & $\begin{array}{l}0 \\
\dot{0} \\
\infty\end{array}$ & $\begin{array}{l}\stackrel{P}{+} \\
\stackrel{\infty}{\infty}\end{array}$ & $\stackrel{O}{\vec{A}}$ & $\stackrel{\circ}{y}$ & 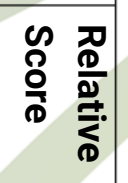 & \\
\hline
\end{tabular}




\begin{tabular}{|c|c|c|c|c|c|c|c|c|c|c|c|c|c|c|c|}
\hline $\begin{array}{l}\frac{\alpha}{D} \\
\frac{\bar{D}}{2}\end{array}$ & 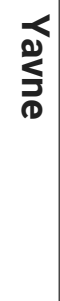 & 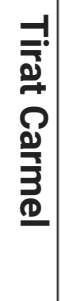 & 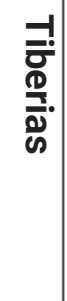 & 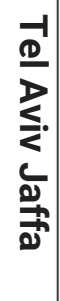 & $\begin{array}{l}\frac{\omega}{\partial} \\
\frac{0}{3} \\
\frac{0}{3}\end{array}$ & $\begin{array}{l}\text { co } \\
\frac{0}{10} \\
\frac{0}{0}\end{array}$ & 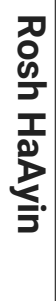 & $\begin{array}{l}\frac{20}{0 .} \\
\overline{0} \\
\frac{0}{3} \\
\overline{0} \\
\frac{0}{N} \\
\overline{0} \\
\end{array}$ & 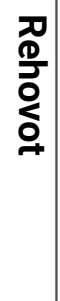 & $\begin{array}{l}\text { Dू } \\
\frac{0}{3} \\
\frac{0}{0}\end{array}$ & 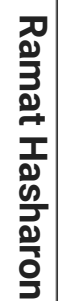 & 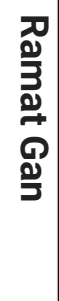 & 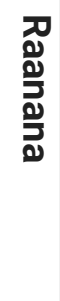 & 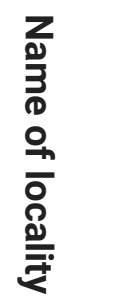 & \\
\hline $\begin{array}{l}\vec{\perp} \\
\infty\end{array}$ & $\frac{N}{\dot{N}}$ & $\stackrel{N}{N}$ & $\stackrel{N}{\sim}$ & $\begin{array}{l}N \\
\infty \\
v\end{array}$ & $\begin{array}{l}\overrightarrow{0} \\
\dot{N}\end{array}$ & $\begin{array}{c}N \\
\infty \\
\infty\end{array}$ & $\begin{array}{l}N \\
\omega \\
\omega\end{array}$ & $\begin{array}{l}\text { Oे } \\
\text { N }\end{array}$ & $\begin{array}{l}\vec{\infty} \\
\sigma\end{array}$ & $\stackrel{N}{+}$ & $\begin{array}{l}\overrightarrow{\vec{v}} \\
\dot{\vec{r}}\end{array}$ & $\frac{N}{\dot{N}}$ & $\vec{\omega}$ & 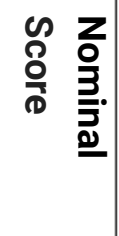 & $\begin{array}{l}\text { D } \\
\text { D. } \\
0 \\
N \\
0 \\
1 \\
\omega \\
\mathbb{D}\end{array}$ \\
\hline $\begin{array}{l}\text { Oे } \\
\text { 今े }\end{array}$ & $\stackrel{O}{\not}$ & $\stackrel{\bigcirc}{\searrow}$ & $\stackrel{O}{\not}$ & $\overrightarrow{8}$ & $\begin{array}{l}\text { 으 } \\
\text { gु }\end{array}$ & $\begin{array}{l}\circ \\
\text { \ْ }\end{array}$ & 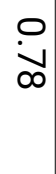 & $\stackrel{\circ}{0}$ & $\begin{array}{l}0 \\
\text { oे } \\
\text { r }\end{array}$ & $\begin{array}{l}0 \\
\text { o } \\
\text { or }\end{array}$ & $\begin{array}{l}0 \\
\text { 잉 }\end{array}$ & $\stackrel{O}{\perp}$ & 영 & 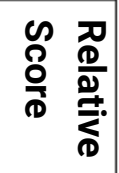 & \\
\hline$\stackrel{v}{v}$ & $\begin{array}{l}\overrightarrow{0} \\
\dot{\omega}\end{array}$ & $\begin{array}{l}\vec{a} \\
\vec{v}\end{array}$ & $\underset{N}{\vec{N}}$ & $\overrightarrow{\overrightarrow{0}}$ & $\stackrel{\vec{N}}{ }$ & $\begin{array}{l}\tilde{\omega} \\
\dot{\omega}\end{array}$ & $\begin{array}{l}\text { Gr } \\
\text { Gr }\end{array}$ & $\begin{array}{l}\vec{\infty} \\
\infty\end{array}$ & $\vec{a}$ & $\begin{array}{l}\overrightarrow{0} \\
\dot{N}\end{array}$ & $\overrightarrow{0}$ & $\overrightarrow{\vec{v}}$ & $\begin{array}{l}\overrightarrow{0} \\
0\end{array}$ & 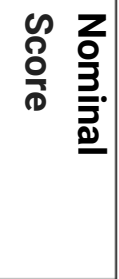 & 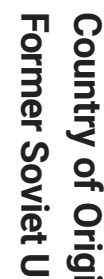 \\
\hline $\begin{array}{l}\circ \\
\vec{v}\end{array}$ & $\begin{array}{l}\text { O } \\
\text { N } \\
\infty\end{array}$ & $\begin{array}{l}0 \\
\text { cे } \\
\text { cr }\end{array}$ & $\stackrel{\circ}{\underset{\perp}{\omega}}$ & $\begin{array}{l}0 \\
\dot{\omega} \\
\infty\end{array}$ & $\stackrel{\circ}{\stackrel{\circ}{\Xi}}$ & $\begin{array}{l}\circ \\
\text { o̊ }\end{array}$ & $\stackrel{\circ}{\vec{G}}$ & $\begin{array}{l}0 \\
\text { ज्ञ }\end{array}$ & $\begin{array}{l}\stackrel{0}{ } \\
\dot{\vec{D}}\end{array}$ & $\begin{array}{l}0 \\
\text { in } \\
\text { N }\end{array}$ & $\begin{array}{l}\stackrel{\circ}{\vec{\omega}} \\
\end{array}$ & $\stackrel{\circ}{\stackrel{\omega}{N}}$ & $\begin{array}{l}0 \\
\text { in }\end{array}$ & 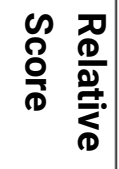 & 궁 \\
\hline $\begin{array}{l}\omega \\
\omega \\
0 \\
\varrho\end{array}$ & $\begin{array}{l}N \\
N \\
N\end{array}$ & $\begin{array}{l}\vec{N} \\
\stackrel{O}{O}\end{array}$ & $\begin{array}{l}\vec{N} \\
\stackrel{\vec{\sigma}}{ }\end{array}$ & $\begin{array}{l}+\infty \\
\underset{\omega}{\omega} \\
\end{array}$ & $\begin{array}{l}\text { w } \\
\infty \\
\text { c) }\end{array}$ & $\begin{array}{l}\vec{a} \\
\dot{N}\end{array}$ & $\begin{array}{l}\omega \\
\stackrel{N}{ } \\
\Delta\end{array}$ & $\begin{array}{l}\omega \\
\vec{\omega} \\
\infty\end{array}$ & $\begin{array}{l}\overrightarrow{0} \\
0 \\
0 \\
+\end{array}$ & $\begin{array}{l}\overrightarrow{0} \\
\dot{\omega} \\
0\end{array}$ & $\begin{array}{l}\text { cr } \\
0 \\
\sigma \\
0\end{array}$ & $\begin{array}{l}\vec{r} \\
0 \\
0\end{array}$ & $\begin{array}{l}\text { ज } \\
\text { or } \\
\text { g }\end{array}$ & 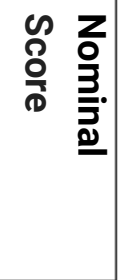 & 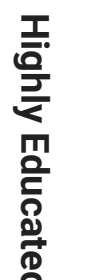 \\
\hline $\begin{array}{l}0 \\
\text { ज }\end{array}$ & 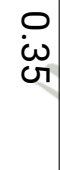 & $\begin{array}{l}0 \\
\dot{N}\end{array}$ & $\begin{array}{l}0 \\
\dot{N}\end{array}$ & $\stackrel{\circ}{\sigma}$ & $\overrightarrow{8}$ & $\stackrel{\circ}{\text { No }}$ & $\begin{array}{l}\text { 음 } \\
\text { or }\end{array}$ & $\begin{array}{l}0 \\
0 \\
0\end{array}$ & $\begin{array}{l}0 \\
\text { ఏे }\end{array}$ & $\begin{array}{l}\stackrel{\circ}{a} \\
\end{array}$ & $\begin{array}{l}\circ \\
\dot{0} \\
\text { v }\end{array}$ & $\stackrel{\circ}{\text { ○े }}$ & $\begin{array}{l}\circ \\
\dot{\infty} \\
\text { o }\end{array}$ & 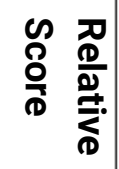 & \\
\hline $\begin{array}{l}\vec{\overrightarrow{ }} \\
\vec{\circ} \\
\stackrel{\omega}{0}\end{array}$ & $\frac{\varrho}{\sigma}$ & w్ & N & $\begin{array}{l}\overrightarrow{0} \\
\infty \\
\infty \\
\infty\end{array}$ & $\begin{array}{l}\vec{D} \\
\text { N }\end{array}$ & $\begin{array}{l}\text { oे } \\
\text { ᄋ }\end{array}$ & $\begin{array}{l}\overrightarrow{0} \\
\text { ○ } \\
\text { cr }\end{array}$ & \begin{tabular}{l}
0 \\
\multirow{2}{\alpha}{} \\
$\sigma$
\end{tabular} & $\begin{array}{l}\overrightarrow{0} \\
\stackrel{\vec{D}}{0} \\
\vec{v}\end{array}$ & 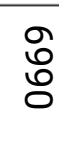 & $\begin{array}{l}\vec{\omega} \\
\underline{\omega} \\
\underline{w}\end{array}$ & $\begin{array}{l}\vec{\circ} \\
\text { 그 }\end{array}$ & $\begin{array}{l}\vec{N} \\
\text { N}\end{array}$ & 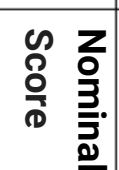 & 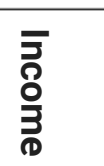 \\
\hline 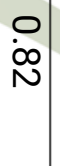 & 웅 & $\stackrel{\circ}{0}$ & $\begin{array}{l}\text { 오 } \\
\text { gे }\end{array}$ & $\begin{array}{l}0 \\
0 \\
1 \\
1\end{array}$ & $\stackrel{\circ}{\stackrel{0}{N}}$ & $\stackrel{\circ}{\text { Ur }}$ & $\begin{array}{l}\text { O } \\
\text { రి }\end{array}$ & $\begin{array}{l}0 \\
\dot{0} \\
\omega\end{array}$ & $\begin{array}{l}0 \\
ن \\
ن\end{array}$ & $\stackrel{\circ}{\text { Vv }}$ & 임 & $\begin{array}{l}\text { ㅇ } \\
\text { প̊ }\end{array}$ & 응 & 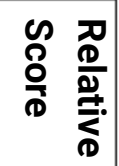 & \\
\hline
\end{tabular}




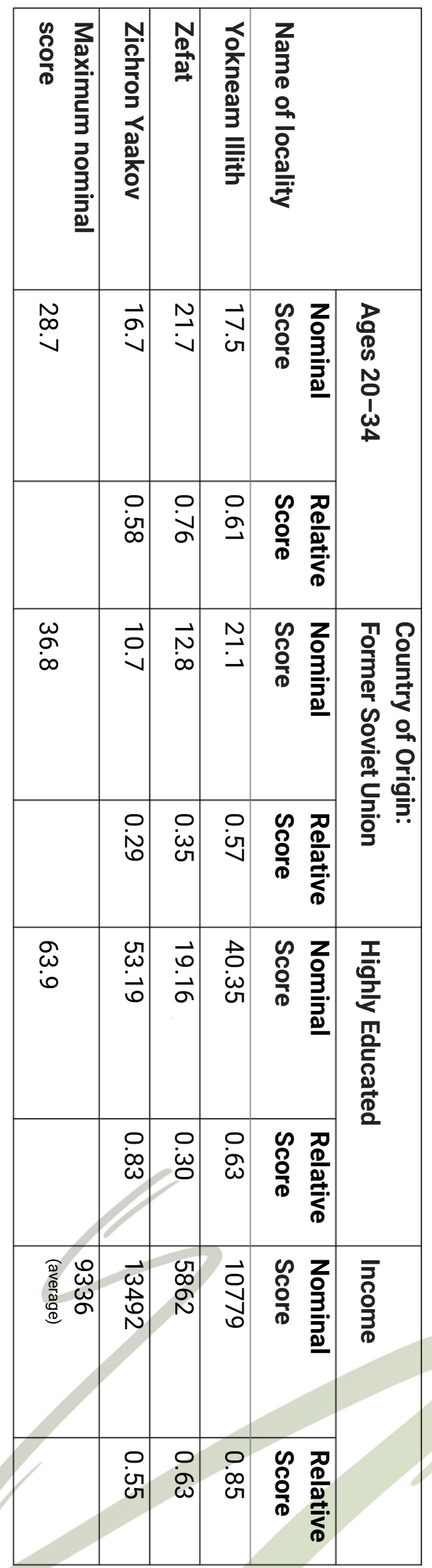


Table A.2. scores, ranking and voting percentage for " $Z$ "

\begin{tabular}{|c|c|c|c|c|c|c|c|}
\hline \multirow[b]{2}{*}{$\begin{array}{l}\text { Name of } \\
\text { locality }\end{array}$} & \multicolumn{2}{|l|}{ EW } & \multicolumn{2}{|l|}{ RS } & \multicolumn{2}{|l|}{ ROS } & \multirow{2}{*}{$\begin{array}{l}\text { Voting } \\
\text { percentage } \\
\text { for " } z \text { " }\end{array}$} \\
\hline & $\begin{array}{l}\text { Nominal } \\
\text { score }\end{array}$ & Rank & $\begin{array}{l}\text { Nominal } \\
\text { score }\end{array}$ & Rank & $\begin{array}{l}\text { Nominal } \\
\text { score }\end{array}$ & Rank & \\
\hline Acre & $57.3 \%$ & 45 & $60.7 \%$ & 33 & $65.9 \%$ & 33 & $2.1 \%$ \\
\hline Afula & $62.1 \%$ & 31 & $63.4 \%$ & 21 & $66.4 \%$ & 21 & $3.2 \%$ \\
\hline Arad & $69.3 \%$ & 9 & $71.3 \%$ & 8 & $72.6 \%$ & 8 & $2.8 \%$ \\
\hline Ariel & $82.8 \%$ & 1 & $86.7 \%$ & 1 & $90.0 \%$ & 1 & $7.4 \%$ \\
\hline Ashdod & $67.5 \%$ & 14 & $66.9 \%$ & 15 & $67.4 \%$ & 15 & $2.8 \%$ \\
\hline Ashkelon & $68.7 \%$ & 10 & $69.3 \%$ & 11 & $70.5 \%$ & 11 & $3.5 \%$ \\
\hline Bat Yam & $67.1 \%$ & 15 & $68.4 \%$ & 13 & $68.6 \%$ & 13 & $2.9 \%$ \\
\hline Beer Sheva & $69.6 \%$ & 8 & $69.1 \%$ & 12 & $70.7 \%$ & 12 & $4.3 \%$ \\
\hline Beit Shean & $46.0 \%$ & 70 & $46.2 \%$ & 67 & $51.4 \%$ & 67 & $2.4 \%$ \\
\hline Beit Shemesh & $57.0 \%$ & 47 & $57.5 \%$ & 43 & $60.0 \%$ & 43 & $3.4 \%$ \\
\hline Carmiel & $75.0 \%$ & 4 & $74.1 \%$ & 6 & $73.5 \%$ & 6 & $3.2 \%$ \\
\hline Dimona & $56.5 \%$ & 51 & $55.9 \%$ & 48 & $59.5 \%$ & 48 & $3.2 \%$ \\
\hline Eilat & $62.7 \%$ & 30 & $64.8 \%$ & 18 & $68.9 \%$ & 18 & $4.0 \%$ \\
\hline Gan Yavne & $54.4 \%$ & 59 & $50.3 \%$ & 61 & $51.5 \%$ & 61 & $3.7 \%$ \\
\hline Ganei Tikva & $49.5 \%$ & 66 & $45.7 \%$ & 69 & $45.3 \%$ & 69 & $2.1 \%$ \\
\hline Gedera & $52.5 \%$ & 62 & $47.4 \%$ & 65 & $47.3 \%$ & 65 & $3.1 \%$ \\
\hline Givat Shmuel & $63.5 \%$ & 29 & $60.0 \%$ & 37 & $59.6 \%$ & 37 & $3.8 \%$ \\
\hline Givatayim & $63.9 \%$ & 28 & $60.7 \%$ & 31 & $61.2 \%$ & 31 & $2.1 \%$ \\
\hline Hadera & $66.3 \%$ & 18 & $64.9 \%$ & 17 & $66.0 \%$ & 17 & $3.0 \%$ \\
\hline Haifa & $80.5 \%$ & 2 & $80.0 \%$ & 2 & $82.4 \%$ & 2 & $2.3 \%$ \\
\hline Herzliya & $61.5 \%$ & 32 & $57.5 \%$ & 42 & $57.4 \%$ & 42 & $2.1 \%$ \\
\hline Hod Hasharon & $54.7 \%$ & 58 & $51.2 \%$ & 60 & $51.0 \%$ & 60 & $1.9 \%$ \\
\hline Holon & $61.2 \%$ & 33 & $56.9 \%$ & 44 & $57.5 \%$ & 44 & $2.7 \%$ \\
\hline Jerusalem & $56.1 \%$ & 54 & $56.0 \%$ & 47 & $60.1 \%$ & 47 & $2.7 \%$ \\
\hline Kadima-Zoran & $56.1 \%$ & 53 & $52.1 \%$ & 59 & $52.2 \%$ & 59 & $2.1 \%$ \\
\hline Kfar Saba & $58.4 \%$ & 43 & $53.8 \%$ & 55 & $53.0 \%$ & 55 & $2.2 \%$ \\
\hline Kfar Yona & $59.4 \%$ & 38 & $53.7 \%$ & 56 & $53.8 \%$ & 56 & $3.1 \%$ \\
\hline
\end{tabular}




\begin{tabular}{|c|c|c|c|c|c|c|c|}
\hline \multirow[b]{2}{*}{$\begin{array}{l}\text { Name of } \\
\text { locality }\end{array}$} & \multicolumn{2}{|l|}{ EW } & \multicolumn{2}{|l|}{ RS } & \multicolumn{2}{|l|}{ ROS } & \multirow{2}{*}{$\begin{array}{l}\text { Voting } \\
\text { percentage } \\
\text { for " } z \text { " }\end{array}$} \\
\hline & $\begin{array}{l}\text { Nominal } \\
\text { score }\end{array}$ & Rank & $\begin{array}{l}\text { Nominal } \\
\text { score }\end{array}$ & Rank & $\begin{array}{l}\text { Nominal } \\
\text { score }\end{array}$ & Rank & \\
\hline Kiryat Ata & $59.8 \%$ & 37 & $58.1 \%$ & 40 & $60.4 \%$ & 40 & $2.9 \%$ \\
\hline Kiryat Bialik & $65.5 \%$ & 22 & $61.8 \%$ & 26 & $62.0 \%$ & 26 & $2.8 \%$ \\
\hline Kiryat Gat & $60.7 \%$ & 35 & $63.9 \%$ & 19 & $67.6 \%$ & 19 & $3.4 \%$ \\
\hline Kiryat Malachi & $53.3 \%$ & 60 & $58.3 \%$ & 39 & $64.4 \%$ & 39 & $3.6 \%$ \\
\hline $\begin{array}{l}\text { Kiryat } \\
\text { Motzkin }\end{array}$ & $67.5 \%$ & 13 & $62.9 \%$ & 22 & $62.7 \%$ & 22 & $2.9 \%$ \\
\hline Kiryat Ono & $49.2 \%$ & 67 & $46.2 \%$ & 68 & $45.9 \%$ & 68 & $1.8 \%$ \\
\hline $\begin{array}{l}\text { Kiryat } \\
\text { Shmona }\end{array}$ & $56.9 \%$ & 48 & $58.4 \%$ & 38 & $62.9 \%$ & 38 & $3.3 \%$ \\
\hline Kiryat Tiv'on & $55.4 \%$ & 55 & $50.1 \%$ & 63 & $49.4 \%$ & 63 & $1.9 \%$ \\
\hline Kiryat Yam & $68.6 \%$ & 11 & $69.7 \%$ & 10 & $70.0 \%$ & 10 & $3.1 \%$ \\
\hline Lod & $58.9 \%$ & 40 & $60.8 \%$ & 30 & $64.0 \%$ & 30 & $3.1 \%$ \\
\hline $\begin{array}{l}\text { Ma'ale } \\
\text { Adumim }\end{array}$ & $64.8 \%$ & 27 & $61.4 \%$ & 28 & $63.1 \%$ & 28 & $5.0 \%$ \\
\hline $\begin{array}{l}\text { Maalot- } \\
\text { Tarshiha }\end{array}$ & $70.8 \%$ & 7 & $72.5 \%$ & 7 & $74.5 \%$ & 7 & $3.5 \%$ \\
\hline $\begin{array}{l}\text { Mevaseret } \\
\text { Zion }\end{array}$ & $59.4 \%$ & 39 & $56.8 \%$ & 45 & $58.6 \%$ & 45 & $2.2 \%$ \\
\hline $\begin{array}{l}\text { Migdal } \\
\text { Haemek }\end{array}$ & $61.0 \%$ & 34 & $62.1 \%$ & 25 & $64.2 \%$ & 25 & $3.0 \%$ \\
\hline $\begin{array}{l}\text { Modi'in } \\
\text { Maccabim- } \\
\text { Reut }\end{array}$ & $58.2 \%$ & 44 & $57.8 \%$ & 41 & $58.3 \%$ & 41 & $2.8 \%$ \\
\hline Nahariya & $65.4 \%$ & 25 & $60.6 \%$ & 34 & $60.5 \%$ & 34 & $3.1 \%$ \\
\hline Nazareth Illit & $74.9 \%$ & 5 & $78.2 \%$ & 3 & $79.7 \%$ & 3 & $3.8 \%$ \\
\hline Nesher & $79.1 \%$ & 3 & $76.0 \%$ & 4 & $75.6 \%$ & 4 & $3.3 \%$ \\
\hline Ness Ziona & $47.7 \%$ & 69 & $44.1 \%$ & 70 & $44.5 \%$ & 70 & $2.4 \%$ \\
\hline Netanya & $68.6 \%$ & 12 & $66.5 \%$ & 16 & $66.4 \%$ & 16 & $3.0 \%$ \\
\hline Netivot & $51.1 \%$ & 63 & $53.3 \%$ & 57 & $58.2 \%$ & 57 & $2.5 \%$ \\
\hline Ofakim & $56.8 \%$ & 49 & $61.4 \%$ & 29 & $66.7 \%$ & 29 & $3.2 \%$ \\
\hline
\end{tabular}




\begin{tabular}{|c|c|c|c|c|c|c|c|}
\hline \multirow[b]{2}{*}{$\begin{array}{l}\text { Name of } \\
\text { locality }\end{array}$} & \multicolumn{2}{|l|}{ EW } & \multicolumn{2}{|l|}{ RS } & \multicolumn{2}{|l|}{ ROS } & \multirow{2}{*}{$\begin{array}{l}\text { Voting } \\
\text { percentage } \\
\text { for " } z \text { " }\end{array}$} \\
\hline & $\begin{array}{l}\text { Nominal } \\
\text { score }\end{array}$ & Rank & $\begin{array}{l}\text { Nominal } \\
\text { score }\end{array}$ & Rank & $\begin{array}{l}\text { Nominal } \\
\text { score }\end{array}$ & Rank & \\
\hline Or Akiva & $64.9 \%$ & 26 & $67.2 \%$ & 14 & $69.3 \%$ & 14 & $3.5 \%$ \\
\hline Or Yehuda & $56.3 \%$ & 52 & $55.7 \%$ & 49 & $59.1 \%$ & 49 & $2.3 \%$ \\
\hline Pardes Hana & $60.0 \%$ & 36 & $53.9 \%$ & 54 & $53.7 \%$ & 54 & $2.8 \%$ \\
\hline Petah Tikva & $65.5 \%$ & 23 & $60.3 \%$ & 36 & $59.7 \%$ & 36 & $2.9 \%$ \\
\hline Raanana & $67.0 \%$ & 16 & $63.9 \%$ & 20 & $62.4 \%$ & 20 & $2.4 \%$ \\
\hline Ramat Gan & $65.4 \%$ & 24 & $61.8 \%$ & 27 & $62.7 \%$ & 27 & $2.7 \%$ \\
\hline $\begin{array}{l}\text { Ramat } \\
\text { Hasharon }\end{array}$ & $50.4 \%$ & 65 & $46.7 \%$ & 66 & $45.8 \%$ & 66 & $1.2 \%$ \\
\hline Ramla & $57.1 \%$ & 46 & $60.4 \%$ & 35 & $65.5 \%$ & 35 & $2.6 \%$ \\
\hline Rehovot & $65.5 \%$ & 21 & $60.7 \%$ & 32 & $60.5 \%$ & 32 & $3.1 \%$ \\
\hline $\begin{array}{l}\text { Rishon } \\
\text { Le'zion }\end{array}$ & $65.8 \%$ & 19 & $62.5 \%$ & 24 & $63.4 \%$ & 24 & $2.8 \%$ \\
\hline Rosh HaAyin & $58.8 \%$ & 41 & $55.0 \%$ & 50 & $57.7 \%$ & 50 & $3.2 \%$ \\
\hline Sderot & $65.6 \%$ & 20 & $70.6 \%$ & 9 & $75.7 \%$ & 9 & $4.4 \%$ \\
\hline Shoham & $55.1 \%$ & 57 & $54.4 \%$ & 52 & $55.2 \%$ & 52 & $3.0 \%$ \\
\hline Tel Aviv Jaffa & $74.6 \%$ & 6 & $75.1 \%$ & 5 & $78.8 \%$ & 5 & $2.0 \%$ \\
\hline Tiberias & $48.4 \%$ & 68 & $50.1 \%$ & 62 & $54.4 \%$ & 62 & $2.5 \%$ \\
\hline Tirat Carmel & $55.1 \%$ & 56 & $56.1 \%$ & 46 & $60.1 \%$ & 46 & $3.1 \%$ \\
\hline Yavne & $58.4 \%$ & 42 & $54.6 \%$ & 51 & $57.2 \%$ & 51 & $3.0 \%$ \\
\hline Yehud & $52.8 \%$ & 61 & $48.0 \%$ & 64 & $49.2 \%$ & 64 & $2.3 \%$ \\
\hline Yokneam Illith & $66.5 \%$ & 17 & $62.7 \%$ & 23 & $61.8 \%$ & 23 & $3.6 \%$ \\
\hline Zefat & $50.8 \%$ & 64 & $53.0 \%$ & 58 & $57.2 \%$ & 58 & $3.3 \%$ \\
\hline $\begin{array}{l}\text { Zichron } \\
\text { Yaakov }\end{array}$ & $56.5 \%$ & 50 & $54.3 \%$ & 53 & $53.9 \%$ & 53 & $2.1 \%$ \\
\hline
\end{tabular}




\section{References}

Abramson, P. R., Aldrich, J. H., Blais, A., Lee., D., \& Levine, R. (2006). Coalition considerations and the vote. In A. Arian and M. Shamir (eds. ), Elections in Israel 2006 (pp.45-66)/ New Brunswick, NJ: Transaction.

Asadabadi, M. R., Chang, E., \& Saberi, M. (2019). Are MCDM methods useful? A critical review of Analytic Hierarchy Process (AHP) and Analytic Network Process (ANP). Cogent Engineering, 6(1), 1623153. DOI: 10.1080/23311916.2019.1623153.

Baines, P. R., Harris, P., \& Lewis, B. R. (2002). The political marketing planning process: improving image and message in strategic target areas. Marketing Intelligence and Planning, 20(1): 6-14.

Bargsted, M. A., \& Kedar, O. (2009). "Coalition-targeted Duvergerian voting: how expectations affect voter choice under proportional representation. " American Journal of Political Science, 53(2): 307-323.

Barron, F., \& Barrett, B. (1996). Decision quality using ranked attribute weights. Management Science, 42(11): 1515-1523.

Bartels, L. (1988). Presidential primaries and the dynamics of public choice. Princeton, NJ: Princeton University Press.

Belton, V. \& Gear, A. E. (1983). On a shortcoming of Saaty's method of analytical hierarchies. Omega, 11(3): 228-230. DOI: 10.1016/0305-0483(83)90047-6.

Blais, A., Aldrich, J. H., Indridason, I. \& Levine, R. (2006). Do voters vote for government coalitions? Testing Downs' pessimistic conclusion. Party Politics, 12(6): 691-705.

Central Bureau of Statistics (CBS). (2018, 16 July). Local Authorities 2016 Data file for processing. Retrieved from

https://old.cbs.gov.il/reader/?Mlval=cw_usr_view_SHTML\&ID=357.

Cohen, M., Noel, H., \& Zaller, J. (2004). From George McGovern to John Kerry: state-level models of presidential primaries, 1972-2004. Conference Papers -- Midwestern Political Science Association, 1-50. Retrieved from https://doirg.ezlibrary.technion.ac.il/mpsa_proceeding_25003.pdf.

Cox, G. W., \& Shugart, M. S. (1996). Strategic Voting under Proportional Representation. Journal of Law Economics and Organization, 12(2): 299-324.

Doumpos, M., \& Zopounidis, C. (2014). Multicriteria analysis in finance. Berlin: Springer. DOI: 10.1007/978-3-319-05864-1.

Farquharson, R. (1969). Theory of voting. New Haven, CT: Yale University Press.

Felsenthal, D. S., \& Brichta, A. (1985). Sincere and strategic voters: an Israeli study. Political Behavior, 7(4): 311-324.

Gordon, B. R., Lovett, M. J., Shachar, R., Arceneaux, K., Moorthy, S., Peress, M., ... \& Urminsky, O. (2012). Marketing and politics: models, behavior, and policy implications. Marketing Letters, 23(2): 391-403. DOI: 10.1007/s11002-012-9185-2. 
Henneberg, S. C. (2008). An epistemological perspective on research in political marketing. Journal of Political Marketing, 7(2): 151-182. DOI: 10.1080/15377850802053158.

Hovav, D. (2017, 16 December). Map of the election results for the 20th Knesset [interactive map]. Retrieved from https://hovavdror.shinyapps.io/DominantParty/

Ishizaka, A. \& Nemery, P. (2013). Multi-criteria decision analysis: methods and software. Hoboken: John Wiley and Sons. DOI: 10.1002/9781118644898.

Krylovas, A., Zavadskas, E. K., Kosareva, N., \& Dadelo, S. (2014). New KEMIRA method for determining criteria priority and weights in solving MCDM problem. International Journal of Information Technology and Decision Making, 13(6): 1119-1133. DOI: $10.1142 /$ S0219622014500825.

Lazarus, J., \& Reiley, S. (2010). The electoral benefits of distributive spending. Political Research Quarterly, 63(2): 343-355.

Lee, P. T.-W., \& Yang, Z. (eds.). (2018). Multi-criteria decision making in maritime studies and logistics. Berlin: Springer. DOI: 10.1007/978-3-319-62338-2.

Levitt, S. D., \& James M. Snyder, J. M. (1997). The impact of federal spending on house election outcomes. The Journal of Political Economy, 105(1): 30-53.

Lilien, G. L., Kotler, P., \& Moorthy, K. S. (1992), Marketing models. Englewood Cliffs, NJ: Prentice-Hall.

Liu, H.-C., Yang, M., Zhou, M., \& Tian, G. (2019). An integrated multi-criteria decision making approach to location planning of electric vehicle charging stations. IEEE Transactions on Intelligent Transportation Systems, 20(1): 362-373. DOI: 10.1109/TITS.2018.2815680.

Noghin, V. D. (2001). What is the relative importance of criteria and how to use it in MCDM? In M. Köksalan \& S. Zionts (eds), Multiple Criteria Decision Making in the New Millennium: Lecture Notes in Economics and Mathematical Systems. Berlin: Springer. DOI: 10.1007/978-3-642-56680-6_5

O'Cass, A. (1996). Political marketing and the marketing concept. European Journal of Marketing, 30(10/11): 37-53. DOI: 10.1108/03090569610149782.

Petrovsky, A. B. (2001). Multi-attribute sorting of qualitative objects in multiset spaces. In M. Köksalan \& S. Zionts (eds.), Multiple Criteria Decision Making in the New Millennium: Lecture Notes in Economics and Mathematical Systems. Berlin: Springer. DOI: 10.1007/978-3-642-56680-6_5.

Poguntke, T., Scarrow, S., \& Webb, P. (2016). Party rules, party resources, and the politics of parliamentary democracies: how parties organize in the 21 st century. Party Politics, 22(6). DOI: $10.1177 / 1354068816662493$.

Rahat, G., \& Hazan, R. Y. (2005). Israel: the politics of an extreme electoral system. In The Politics of Electoral Systems (pp. 333-351). Oxford: Oxford University Press.

Results of the 20th Knesset elections. (2015, 29 March). Retrieved from https://votes20.gov.il/ Results of the 2015 elections by neighbourhood (2019, 2 February). Retrieved from 
https://www.madlan.co.il/elections/2015.

Results of the 21st Knesset elections. (2019, 20 April). Retrieved from https://votes21.bechirot.gov.il/.

Saaty, T. L., (1977). A scaling method for priorities in hierarchical structures. Journal of Mathematical Psychology, 15(3): 234-281.

Saaty, T. L. (1980). The analytic hierarchy process. New York: McGraw-Hill.

Saaty, T. L. (1990). How to make a decision: the analytic hierarchy process. European Journal of Operational Research, 48(1): 9-26.

Shachar, R. (2009). The political participation puzzle and marketing. Journal of Marketing Research, 46(6): 798-815.

Shea, D. M. (1996). Campaign craft: the strategies, tactics, and art of political campaign management. Westport, CT: Praeger Publishers.

Squire, P. (1995). Candidates, money, and voters: assessing the state of congressional elections research. Political Research Quarterly, 48(4): 891-917.

Shugart, M. S. (2011) Political-institutional reform in Israel: a comparative perspective, Jerusalem: Israel Democracy Institute.

Snyder, J. (1989). Election goals and the allocation of campaign resources. Econometrica, 57(3): 637-660. DOI: $10.2307 / 1911056$

Thokala, P., Devlin, N., Marsh, K., Baltussen, R., Boysen, M., Kalo, Z., ... \& ljzerman, M. (2016). Multiple criteria decision analysis for health care decision making - An introduction: Report 1 of the ISPOR MCDA Emerging Good Practices Task Force. Value in Health, 19(1). DOI: 10.1016/j. jval.2015.12.003.

Triantaphyllou, E. (2000). Multi-criteria decision making methods: a comparative study. New York: Springer US.

Utkin, L. V. (2014). Reducing the Pareto optimal set in MCDM using imprecise probabilities. International Journal of Operational Research, 19(1): 21-39.

Zopounidis, C., \& Doumpos, M. (eds.). (2017). Multiple criteria decision making: applications in management and engineering. Berlin: Springer. DOI: 10.1007/978-3-319-39292-9. 